\title{
New Perspectives on Migration into the Tlajinga District of Teotihuacan: A Dual-Isotope Approach
}

\author{
Gina M. Buckley (D, Rebecca Storey, Fred J. Longstaffe, David M. Carballo, Kenneth G. Hirth, \\ and Virginie Renson
}

\begin{abstract}
The city of Teotihuacan (AD 1-550) was a major multiethnic urban center that attracted migrants from as far away as west Mexico and the Maya region. Past research in the Tlajinga district at Teotihuacan using oxygen isotopes from human remains estimated that nearly $30 \%$ of the population of Tlajing a 33, a single apartment compound, were migrants. This study takes a dual-isotope approach $\left({ }^{87} \mathrm{Sr}{ }^{86} \mathrm{Sr}\right.$ and $\left.\delta^{18} \mathrm{O}_{\mathrm{p}}\right)$ to reevaluate the proportion of in-migration at Tlajinga and includes data from two additional apartment compounds, Tlajinga 17 and $18(\mathrm{n}=23)$. New results indicate that migrants comprised $\sim 45 \%$ of the Tlajinga population. Previously acquired radiocarbon dates combined with mortuary and isotope data suggest that immigration to Tlajinga was highest during the first centuries of compound occupation. Nevertheless, migration was a continual process throughout its history. Additionally, a new finding suggests that residents of Tlajinga 33 ingested foods with higher ${ }^{87} \mathrm{Sr} /{ }^{86} \mathrm{Sr}$ ratios than did those of Tlajinga 17 and 18. We hypothesize that the incorporation of imported lime for the nixtamalization process skewed the ${ }^{87} \mathrm{Sr}{ }^{86} \mathrm{Sr}$ ratios of human remains, a potentially important finding for future studies at Teotihuacan.
\end{abstract}

Keywords: Teotihuacan, strontium isotopes, oxygen isotopes, migration, population, nixtamalization

La ciudad de Teotihuacán (1-550 dC) fue un importante centro urbano multiétnico a lo cual llegaron inmigrantes desde el oeste de México y la región Maya. Una investigación previa en el distrito de Tlajinga utilizó isótopos de oxígeno de los huesos y esmalte de los dientes para estimar que casi el 30\% de la población de Tlajinga 33 eran migrantes. Este estudio utiliza dos isótopos $\left({ }^{87} \mathrm{Sr}{ }^{86} \mathrm{Sr}\right.$ y $\left.\delta^{18} \mathrm{O}_{\mathrm{p}}\right)$ para reevaluar la proporción de inmigración en Tlajinga, incluidos los datos de los complejos de residenciales, Tlajinga 17 y $18(\mathrm{n}=23)$. Los nuevos resultados indican que los migrantes comprendían $~ 45 \%$ de la población de Tlajinga. La datación de radiocarbono, las ofrendas de cerámica, y los datos de isótopos indican que la inmigración a Tlajinga fue más alta durante los primeros siglos de ocupación, aunque la migración fue un proceso continuo a lo largo de la historia del complejo. Además, un nuevo hallazgo indica que los residentes de Tlajinga 33 comieron alimentos con mayores proporciones ${ }^{87} \mathrm{Sr} /{ }^{86} \mathrm{Sr}$ en comparación con Tlajinga 17 y 18. Presentamos la hipótesis de que la incorporación de cal importada para el proceso de nixtamalización elevó las proporciones ${ }^{87} \mathrm{Sr} /{ }^{86} \mathrm{Sr}$ en esqueletos humanos, un hallazgo potencialmente importante para estudios futuros en Teotihuacan y Mesoamérica.

Palabras claves: Teotihuacan, isótopos de estroncio, isótopos de oxígeno, migración, población, nixtamalización

$\mathrm{M}$ igration into the ancient city of Teotihuacan (AD 1-550) is one of the most complex and least understood

demographic developments of any prehispanic urban center (Smith 2020). Past research demonstrates that Teotihuacan attracted migrants in its

Gina M. Buckley (gmb226@psu.edu, corresponding author) and Kenneth G. Hirth $\mathbf{a}$ Department of Anthropology, Pennsylvania State University, 410 Carpenter Building, University Park, PA 16802, USA

Rebecca Storey Anthropology Program, Department of Comparative Studies, University of Houston, 3623 Cullen Blvd., Room 223, Houston, TX 77204, USA

Fred J. Longstaffe $\square$ Department for Earth Sciences, University of Western Ontario, London, Ontario, N6A 5B7, Canada David M. Carballo $\square$ Department of Anthropology and Archaeology Program, Boston University, 675 Commonwealth Ave., Boston, MA 02215, USA

Virginie Renson $\mathbf{a}$ Research Reactor Center, University of Missouri-Columbia, 1513 Research Park Drive, Columbia, MO 65211, USA

Latin American Antiquity 32(3), 2021, pp. 536-556

Copyright (C) The Author(s), 2021. Published by Cambridge University Press on behalf of the Society for American Archaeology. This is an Open Access article, distributed under the terms of the Creative Commons Attribution licence (http://creativecommons.org/licenses/by/4.0/), which permits unrestricted re-use, distribution, and reproduction in any medium, provided the original work is properly cited.

doi:10.1017/laq.2021.20 
early years of urban development (Millon 1973, 1981) and that in-migrants inhabited specific neighborhoods throughout the occupation of the city (Clayton 2005; Gómez Chávez 2002; Manzanilla 2011; Michelet and Pereira 2009; Rattray 2004; Solís Pichardo et al. 2017; Spence et al. 2005; Taube 2003; White, Spence, et al. 2004; White, Storey, et al. 2004). However, archaeometry data combining radiocarbon dates and isotopic measurements have never been formally tested to determine whether in-migration at Teotihuacan was highest at the city's founding or remained constant across the centuries as an integral component of sustaining the urban population. Additionally, we do not yet understand whether specific demographic groups were more inclined than others to immigrate to Teotihuacan.

This study reevaluates previous estimates of migration at the Tlajinga district of Teotihuacan (Figure 1) through a dual-isotope approach using strontium $\left({ }^{87} \mathrm{Sr} /{ }^{86} \mathrm{Sr}\right)$ and stable oxygenphosphate $\left(\delta^{18} \mathrm{O}_{p}\right)$ isotope data from human remains $(n=23)$. Refinements are made to the local ${ }^{87} \mathrm{Sr} /{ }^{86} \mathrm{Sr}$ ratio baseline ranges for the Teotihuacan Valley. We couple isotopic data with previously reported high-precision radiocarbon dates (Storey et al. 2019:155) to observe diachronic migration in three compounds across the Tlajinga district. We also test for significant differences in isotopic signatures between residential and demographic groups to identify specific types of people who migrated to Tlajinga. For the first time at Teotihuacan, we consider how imported maize-enhancing materials used in the nixtamalization process potentially skew the ${ }^{87} \mathrm{Sr} /{ }^{86} \mathrm{Sr}$ signatures of individuals in this region.

Teotihuacan is located $45 \mathrm{~km}$ northeast of modern-day Mexico City and is spread across $25 \mathrm{~km}^{2}$ in the Teotihuacan Valley, an extension of the greater Basin of Mexico. It was the first city in the Americas to reach a population of 100,000 , which it did during the Classic period (AD 200-550; Cowgill 2015:143; Smith et al. 2019). It is hypothesized that migrants were attracted to the city from across Mesoamerica, because Teotihuacan offered economic opportunity and the potential for individuals to rise in social status (Spence et al. 2005). Residents of Teotihuacan constructed apartment compounds, which were not seen before in the Americas nor again before Spanish contact. These residential structures were large, multifamily complexes, typically with shared lineal descent, cultural practices, and forms of craft specialization (Carballo 2011; Cowgill 2015:142; Manzanilla 1996).

Teotihuacan comprised a vast network of residential districts, as is described in the Teotihuacan Mapping Project (Millon 1973). Accordingly, research on in-migration has historically been conducted at the neighborhood level (Manzanilla 2017; Spence et al. 2005; Storey 1992; White, Spence, et al. 2004; White, Storey, et al. 2004), and the results were then consolidated to allow citywide comparisons of demographic events and mortuary practices. Here, we continue this practice and revisit the southernmost district of Tlajinga. We offer additional isotopic analyses for Compound 33:S3W1 (“Tlajinga 33”), along with new data from two recently excavated residential units: Compounds 17:S3E1 ("Tlajinga 17") and 18:S3E1 (“Tlajinga 18”).

Located on the southern periphery of the city, the Tlajinga district was connected to the central urban hub by an extension of the Street of the Dead (Figure 1). Unlike apartment compounds near the epicenter, those in Tlajinga were spaced farther apart and characterized by a mix of adobe and stone walls, the minimal use of lime plaster, and a lack of murals. These features imply that the district was made up of lower-status residents (Carballo et al. 2019; Storey 1992; Widmer 1987). However, several burials from Tlajinga 33 contain elaborate mortuary offerings or are distinguished by a large tomb interment, thereby signifying the existence of compound leaders (Storey et al. 2019:158; Figure 2). This compound also appeared to be a focal point of ceramic production, particularly of the San Martín Orange ware that was distributed citywide and was popular in the later phases of the city's occupation (Cowgill 2015:173; Sheehy 1992). Additionally, recent excavations identify Tlajinga 17 as the location of a large obsidian workshop (Hirth et al. 2019) and the source for large outputs of lapidary crafts (Widmer 2019).

The demography and health of the inhabitants of Tlajinga 33 are discussed in Storey (1992). 


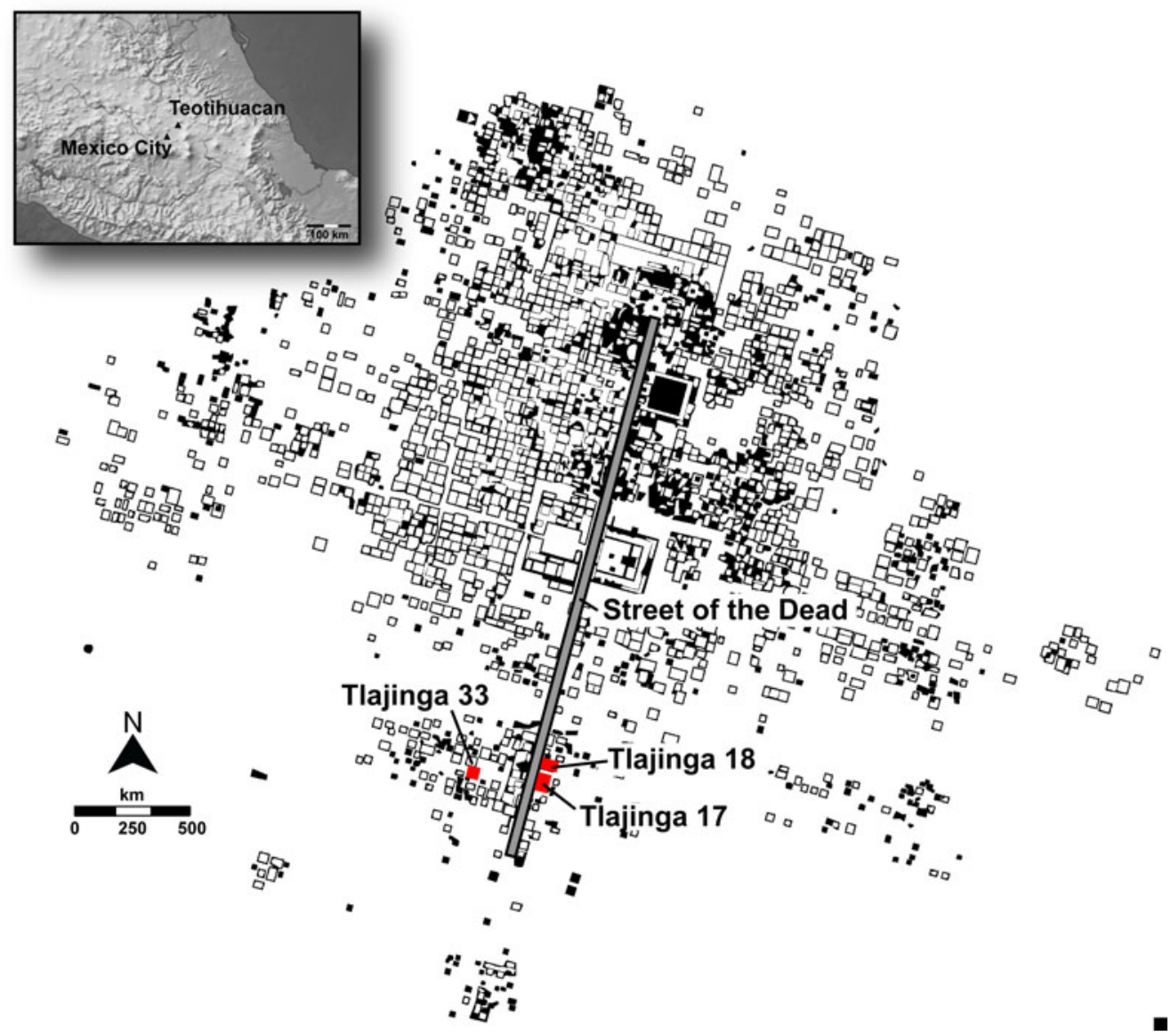

Figure 1. Teotihuacan with apartment compounds Tlajinga 17, 18, and 33 shown in relation to the greater city.

Residents of Tlajinga 33 fought an uphill battle with morbidity: the population suffered a steady decline due to high infant mortality rates caused mostly by prenatal malnutrition or illness (Storey 1992:255). Skeletal observations from Compounds 17 and 18, although small in sample size $(n=9)$, show similar morbidity patterns (Storey et al. 2019:Figure 1, 151). Therefore, we support Storey's (1992) hypothesis that continual migration into the Tlajinga district was necessary to maintain population stability.

In an earlier test of this hypothesis, White, Storey, and colleagues (2004) measured the oxygen isotope composition of bioapatite phosphate $\left(\delta^{18} \mathrm{O}_{p}\right)$ in human bone and tooth enamel for 25 individuals. Those results indicated that $\sim 30 \%$ of sampled individuals from Tlajinga $33 \mathrm{had}$ signatures outside the local $\delta^{18} \mathrm{O}_{p}$ baseline range.
Perhaps most surprising, this study found that higher-status individuals tended to be those who "spent time in a foreign location" (White, Storey, et al. 2004:189).

Until recently, $\delta^{18} \mathrm{O}_{p}$ analysis was the predominant method of identifying migrant individuals in Teotihuacan (White et al. 2002, 2007; White, Spence, et al. 2004; White, Storey, et al. 2004). A multi-isotope approach has now been shown to more reliably identify nonlocal individuals within a region (e.g., Wright 2012). Thus, earlier studies based on a single isotopic system can benefit from the examination of additional isotopic systems at any region or site. Futhermore, the acquisition of high-precision accelerated mass spectrometry (AMS) radiocarbon $\left({ }^{14} \mathrm{C}\right)$ dates in tandem with isotopic analysis provides key insights to migration over time, but 


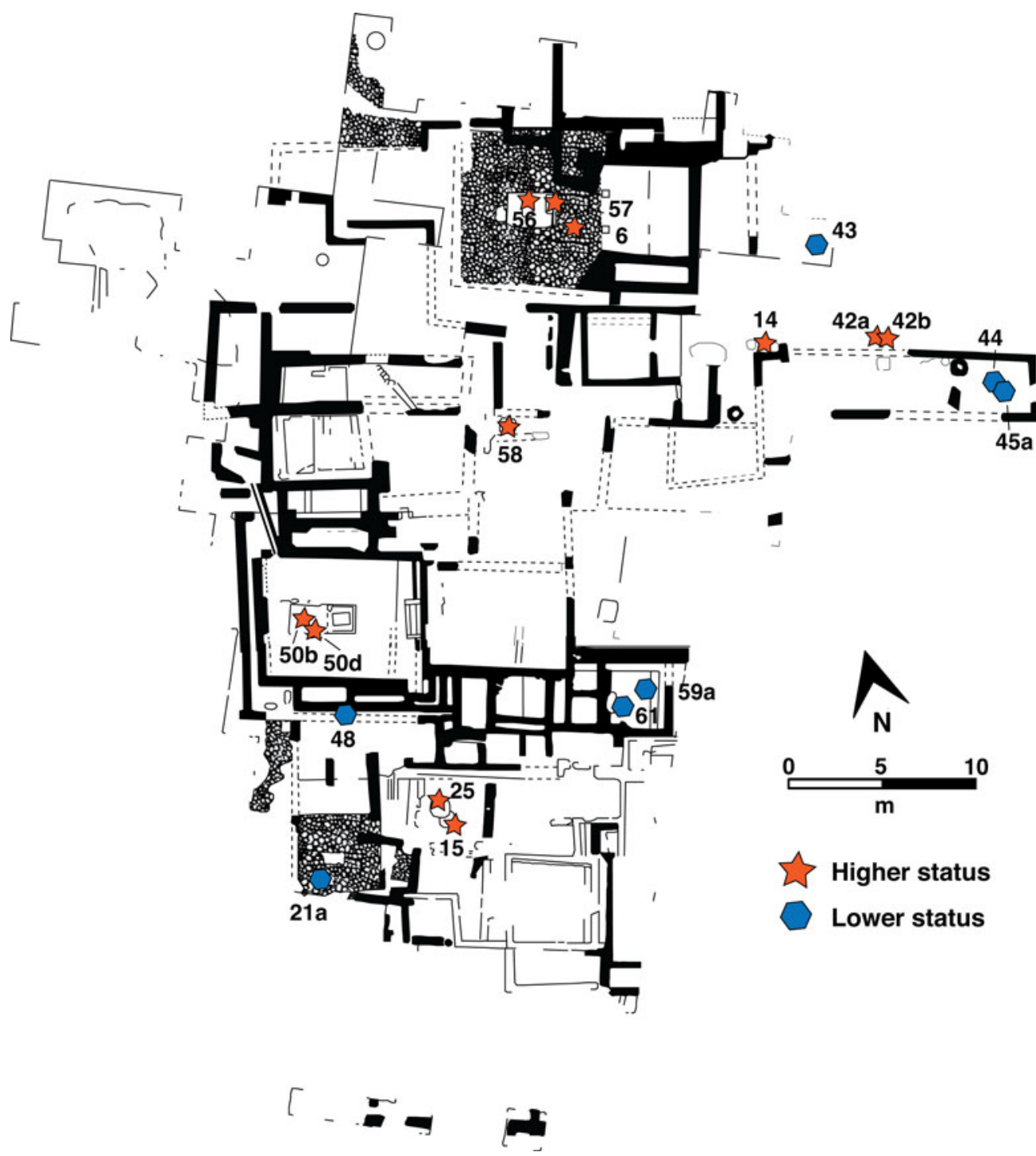

Figure 2. The Tlajinga 33 compound. Burials mentioned in the text are labeled. Adapted from Storey (1992:Figure 3-2). The distribution of burials at Tlajinga 17 and 18 can be viewed in Storey and colleagues (2019:Figure 1).

this coupling of datasets has not been previously realized at Teotihuacan.

\section{Benefits of a Dual-Isotope Approach $\left({ }^{87} \mathrm{Sr} /{ }^{86} \mathrm{Sr}\right.$ and $\left.\delta^{18} \mathrm{O}_{p}\right)$}

The benefits of a dual-isotope approach stem from the fact that strontium ( $\mathrm{Sr}$ ) and oxygen (O) from the surrounding environment are absorbed into human tissues from different aspects of the diet: $\mathrm{Sr}$ from food (and water, to a lesser extent) and $\mathrm{O}$ from water ingested over the life cycle. Thus, each isotopic system provides unique provenance measurements that can be used to determine patterns of residential mobility throughout an individual's life span (see Bentley 2006; Pederzani and Britton 2019).

In Mesoamerica, the combination of strontium and oxygen isotope analyses has already been a significant contributor to understanding paleomobility. Wright (2012) analyzed these 
isotopic systems at the ancient Maya city of Tikal to demonstrate that in-migration of people from all socioeconomic tiers contributed to the city's rapid population growth. In Teotihuacan, White and colleagues (2007) first used strontium and oxygen isotopes to identify many of the sacrificial individuals from the Moon Pyramid as foreign-born. More recently, Price and coauthors (2020) revisited the sacrificial individuals of the Feathered Serpent Pyramid at Teotihuacan, initially analyzed for $\delta^{18} \mathrm{O}_{p}$ by White and colleagues (2002), and applied new strontium and oxygen-carbonate isotope analyses. The new findings suggest that some of these sacrificed individuals were local to the central Highlands of Mexico rather than part of an ethnically diverse military, as was suggested in the intial study (White et al. 2002).

When using isotope analyses to detect paleomobility, researchers must consider whether individuals were eating foods and drinking water obtained from the same geological and environmental region in which they resided. Therefore, one must first understand a population's diet before successfully implementing isotopic studies to identify migration (Nado et al. 2017; Wright 2012). At Tlajinga, past studies of stable carbon $\left(\delta^{13} \mathrm{C}\right)$ and nitrogen $\left(\delta^{15} \mathrm{~N}\right)$ isotopes suggest that residents from all three compounds consumed a maize-heavy diet and did not import a significant amount of marinederived food (Storey et al. 2019; White, Storey, et al. 2004). Additionally, Teotihuacan was surrounded by maize-producing agricultural fields (Nichols et al. 1991). Therefore, we are confident in assuming that Tlajinga residents ingested primarily locally produced foods.

\section{Materials and Methods}

Numerous studies have found that tooth enamel bioapatite more reliably preserves original biogenic isotopic compositions than bone (e.g., Grimes and Pellegrini 2013). Furthermore, different teeth within the human mouth develop at various known ages during the early years of human development (Hillson 1996). Once tooth crown formation is completed, human enamel does not undergo further turnover. Human bone, by comparison, continuously remodels throughout the life span. Enamel's resistance to remodeling in vivo after tooth crown formation is complete provides researchers with a tissue that essentially locks in isotopic signatures acquired during childhood development (Montgomery et al. 2010). Therefore, in this study, we analyzed human tooth enamel for ${ }^{87} \mathrm{Sr} /{ }^{86} \mathrm{Sr}$ and $\delta^{18} \mathrm{O}_{p}$, rather than bone.

\section{Sample Selection}

Tooth enamel data for a total of 23 individuals are reported in this study $(n=39$ tooth enamel samples in total): 18 individuals $(n=30$ enamel samples) for ${ }^{87} \mathrm{Sr} /{ }^{86} \mathrm{Sr}$ ratios and 14 individuals ( $n=22$ enamel samples) for $\delta^{18} \mathrm{O}_{p}$. The $\delta^{18} \mathrm{O}_{p}$ values for eight of these individuals ( $n=9$ enamel samples) were initially reported by White, Storey, and colleagues (2004:180-181). Consistent with past $\delta^{18} \mathrm{O}_{p}$ studies conducted at Teotihuacan (White, Spence, et al. 2004; White, Storey, et al. 2004), the measured $\delta^{18} \mathrm{O}_{p}$ values were adjusted downward by $0.35 \%$ o for premolars, and $0.7 \%$ for all teeth developed before three to four years of age, because this is the accepted prehistoric weaning age in this region (Wright 2013). The $\delta^{18} \mathrm{O}$ of bioapatite phosphate and structural carbonate in enamel wholly formed during breastfeeding is commonly higher by $\sim 0.7 \%$ compared to similar tissues formed or remodeled after the breastfeeding period (White et al. 2000; Wright and Schwartz 1999). This difference reflects the trophic step associated with the incorporation of maternal body water during breastfeeding.

Samples were obtained from apartment compounds within the Tlajinga district, Tlajinga 17 $(n=2)$, Tlajinga $18 \quad(n=3)$, and Tlajinga 33 $(n=18)$. Individuals analyzed by White, Storey, and colleagues (2004) who only had $\delta^{18} \mathrm{O}_{p}$ values for bone were excluded from this study, so that we compared only oxygen isotope results reflecting early life developmental phases. When available, two teeth from each adult individual were selected for isotopic analysis based on the known ages of tooth crown formation and completion (Hillson 1996). We identify these phases as early childhood (EC), representing birth through age 5, and late childhood/adolescence (LCA), representing ages 12-16. Due to the lack of material for some specimens included 
in this study, $\mathrm{Sr}$ and $\mathrm{O}$ isotope results are not available for all individuals.

The use of isotopes in migration studies requires the availability of a baseline. For strontium isotopes, the most robust technique for estimating regional baselines is to gather a range of isotopic ratios that reflect any possible geological (bedrock), environmental (soil, water), or bioavailable (plants, fauna, human) signatures that could be considered local to the region of study (Adams et al. 2019; Grimstead et al. 2017). To complement the existing baseline for local ${ }^{87} \mathrm{Sr} /{ }^{86} \mathrm{Sr}$ ratios in the Teotihuacan Valley (see Price et al. 2000; Schaaf et al. 2012), we analyzed additional faunal samples collected from the 2013-2014 Proyecto Arqueológico Tlajinga Teotihuacan (PATT) excavations and water samples from groundwater across the Teotihuacan Valley $(n=14)$. We chose to use tooth enamel from rabbits and rodents, because these animals have small home ranges (see Sommerville et al. 2018).

\section{Statistical Analysis}

All statistical analyses were conducted in the $\mathrm{R}$ statistical software package (Core Team, 2017). We used hierarchical cluster analysis to observe significantly different groups of individuals for which there are measurements of both ${ }^{87} \mathrm{Sr} /{ }^{86} \mathrm{Sr}$ and $\delta^{18} \mathrm{O}_{p}$. Here, we tested models that imposed two, three, four, and five clusters. One-way ANOVA was then performed to test for significant differences in mean isotopic compositions across each cluster. The $\mathrm{R}$ code for this analysis is included in Supplemental Text 1. For four burials-33-15, 33-50d, 33-56, and 33-57-EC and LCA enamel were included from the same individual to identify whether isotopic measurements were significantly different throughout childhood.

We created groups based on the following demographic characteristics: time period based on the ceramic chronology (Tlamimilolpa/Xolalpan phases), compound (Tlajinga 17 and 18/Tlajinga 33), status (higher/lower), and sex (female/ male). We also tested for differences across time using ${ }^{14} \mathrm{C}$ dates (reported in Storey et al. 2019:155). Here, we divide individuals into three groups designated by the dominant economic production efforts of Tlajinga 33 at the time: lapidary (crafts; cal AD 200-350), transition (from lapidary crafts to San Martín Orange ware production; cal AD 300-450), and San Martín (Orange ware; cal AD 400-550). Shapiro-Wilk and Levene's tests were conducted to determine the normality of sample distributions and assess the equality of variances. We then performed parametric Student's $t$-tests or nonparametric Mann-Whitney $U$ tests to determine whether there were significant differences between group means. One-way ANOVA or Kruskal-Wallis tests were used to detect significant differences between combined demographic data (e.g., compound and status, compound and time periods) and between the time groups using ${ }^{14} \mathrm{C}$ dates. Supplemental Text 2 describes the methodology used to obtain the isotopic data in this study.

\section{Results and Discussion}

\section{Isotopic Baselines in the Teotihuacan Valley}

$\mathrm{The}{ }^{87} \mathrm{Sr} /{ }^{86} \mathrm{Sr}$ ratios measured in this study for the regional baseline of the Teotihuacan Valley range from 0.70432 to 0.70499 (which we rounded to 0.7043 and 0.7050 ; see Supplemental Table 1). The highest measured ${ }^{87} \mathrm{Sr} /{ }^{86} \mathrm{Sr}$ ratio is from one water sample procured from a contemporary well near Teotihuacan. Without this sample, the maximum value of the range would be closer to 0.7048 . Previously reported ranges of the ${ }^{87} \mathrm{Sr} /{ }^{86} \mathrm{Sr}$ baseline from faunal samples were from 0.7046 to 0.7047 (Price et al. 2000). In a recent study, Price and colleagues (2020) concluded that Teotihuacan and its nearby neighbors should have ${ }^{87} \mathrm{Sr} /{ }^{86} \mathrm{Sr}$ ratios between 0.7040 and 0.7050 , supporting our new assessment of the baseline.

For Teotihuacan, the accepted $\delta^{18} \mathrm{O}_{p}$ baseline range is +14 to $+16 \%$, as first reported by Levinson and colleagues (1987). White, Storey, and others (2004) corroborated this range, noting that individuals from the Tlajinga district had a mean $\delta^{18} \mathrm{O}_{p}$ of $+15 \%$ and that the typical regional variation for locals is about $2 \%$.

\section{Identifying Migrants at Teotihuacan}

Table 1 reports the isotopic measurements of tooth enamel specimens and the demographic data for each individual. The strontium and 
Table 1. Isotopic Parameters by Individual and Compound.

\begin{tabular}{|c|c|c|c|c|c|c|c|c|c|c|}
\hline Burial \# & Sample \# & Age at Death (years) & Sex & Time Period & Status & Tooth & Tooth Phase & ${ }^{87} \mathrm{Sr} /{ }^{86} \mathrm{Sr}$ & $\mathrm{Sr}(\mathrm{ppm})$ & $\overline{\delta^{18} \mathrm{O}_{p}(\% \mathrm{VSMOW})}$ \\
\hline \multicolumn{11}{|c|}{ Compound 17} \\
\hline $17-5$ & $17-5-1$ & Adult & M & Late Tlamimilolpa & Lower & $\mathrm{I}^{1}$ & $\mathrm{EC}$ & 0.70494 & 361 & - \\
\hline $17-7$ & 17-7-1 & $30-50$ & M & Late Tlamimilolpa & Lower & $\mathrm{LI}^{1}$ & $\mathrm{EC}$ & 0.70484 & 201 & - \\
\hline \multicolumn{11}{|c|}{ Compound 18} \\
\hline $18-1$ & 18-1-1 & $60+$ & M & - & Lower & $\mathrm{I}^{1}$ & $\mathrm{EC}$ & 0.70486 & 197 & - \\
\hline $18-2 \mathrm{a}$ & $18-2 a-1$ & $40-50$ & $\mathrm{~F}$ & - & Lower & M1 & $\mathrm{EC}$ & 0.70491 & 197 & - \\
\hline \multirow[t]{2}{*}{$18-3 b$} & $18-3 b-1$ & $30-50$ & $\mathrm{~F}$ & Early Xolalpan & Lower & $\mathrm{I}_{2}$ & $\mathrm{EC}$ & 0.70485 & 300 & - \\
\hline & $18-3 b-2$ & & & & & $\mathrm{M}_{3}$ & LCA & 0.70487 & 434 & +15.9 \\
\hline \multicolumn{11}{|c|}{ Compound 33} \\
\hline $33-6$ & $33-6-1^{a}$ & $45-55$ & $\mathrm{~F}$ & Early Tlamimilolpa & Higher & $\mathrm{RP}_{3}$ & LCA & - & - & +11.3 \\
\hline \multirow[t]{2}{*}{$33-14$} & $33-14-1$ & $40-50$ & $\mathrm{~F}$ & Late Tlamimilolpa & Higher & $\mathrm{I}_{1}$ & $\mathrm{EC}$ & 0.70530 & 152 & - \\
\hline & $33-14-2$ & & & & & $\mathrm{M}^{3}$ & LCA & 0.70513 & 289 & $+18.1^{\mathrm{b}}$ \\
\hline \multirow[t]{2}{*}{$33-15$} & $33-15-1$ & $20-30$ & $\mathrm{~F}$ & Late Tlamimilolpa & Higher & $\mathrm{M}_{1}$ & $\mathrm{EC}$ & 0.70550 & 146 & $+15.0^{\mathrm{b}}$ \\
\hline & $33-15-2$ & & & & & $\mathrm{M}^{3}$ & LCA & 0.70498 & 309 & $+14.2^{\mathrm{b}}$ \\
\hline \multirow[t]{2}{*}{$33-21 \mathrm{a}$} & $33-21 a-1$ & $2-3$ & - & Late Tlamimilolpa & Lower & $i^{2}$ & $\mathrm{EC}$ & 0.70493 & 344 & - \\
\hline & $33-21 a-2$ & & & & & $\mathrm{~m}_{1}$ & $\mathrm{EC}$ & 0.70488 & 288 & - \\
\hline \multirow[t]{2}{*}{$33-25$} & $33-25-1$ & $50-60$ & $\mathrm{~F}$ & Late Tlamimilolpa & Higher & $\mathrm{I}_{1}$ & $\mathrm{EC}$ & 0.70418 & 289 & - \\
\hline & $33-25-2$ & & & & & $\mathrm{C}_{1}$ & $\mathrm{EC}$ & 0.70431 & 337 & - \\
\hline $33-42 a$ & $33-42 a-1^{a}$ & $45-55$ & M & Late Tlamimilolpa & Higher & $\mathrm{RC}_{1}$ & $\mathrm{EC}$ & - & - & +14.5 \\
\hline \multirow[t]{2}{*}{$33-42 b$} & $33-42 b-1^{a}$ & $50-60$ & M & Late Tlamimilolpa & Higher & $\mathrm{RC}_{1}$ & $\mathrm{EC}$ & - & - & +15.0 \\
\hline & $33-42 b-2^{a}$ & & & & & $\mathrm{LI}_{2}$ & $\mathrm{EC}$ & - & - & +14.4 \\
\hline \multirow[t]{2}{*}{$33-43$} & $33-43-1$ & $40-50$ & M & Late Tlamimilolpa & Lower & $\mathrm{RM}_{1}$ & $\mathrm{EC}$ & 0.70565 & 111 & - \\
\hline & $33-43-2$ & & & & & $\mathrm{LM}_{3}$ & LCA & 0.70570 & 220 & +16.4 \\
\hline $33-44$ & $33-44-1^{\mathrm{a}}$ & $45-55$ & M & Late Tlamimilolpa & Lower & $\mathrm{RI}_{2}$ & $\mathrm{EC}$ & - & - & +17.1 \\
\hline $33-45 a$ & $33-45 a-1^{a}$ & $40-50$ & M & Late Tlamimilolpa & Lower & $\mathrm{RI}^{1}$ & $\mathrm{EC}$ & - & - & +16.3 \\
\hline \multirow[t]{2}{*}{$33-48$} & $33-48-1$ & Adols & - & Early Xolalpan & Lower & $\mathrm{M}_{1}$ & $\mathrm{EC}$ & 0.70494 & 191 & - \\
\hline & $33-48-2$ & & & & & $\mathrm{I}_{2}$ & $\mathrm{EC}$ & 0.70489 & 198 & - \\
\hline \multirow[t]{3}{*}{$33-50 b$} & $33-50 b-1$ & $40-50$ & M & Late Xolalpan & Higher & $\mathrm{RM}_{1}$ & $\mathrm{EC}$ & 0.70512 & 246 & $+14.7^{\mathrm{b}}$ \\
\hline & $33-50 b-2$ & & & & & $\mathrm{I}_{1}$ & $\mathrm{EC}$ & 0.70497 & 132 & - \\
\hline & $33-50 b-3^{a}$ & & & & & $\mathrm{RM}_{3}$ & LCA & - & - & +17.2 \\
\hline \multirow[t]{3}{*}{$33-50 d$} & $33-50 \mathrm{~d}-1$ & $50-60$ & M & Early-Late Xolalpan & Higher & $\mathrm{RM}_{1}$ & $\mathrm{EC}$ & 0.70510 & 159 & +16.3 \\
\hline & $33-50 d-2^{a}$ & & & & & $\mathrm{RP}_{4}$ & LCA & - & - & +17.3 \\
\hline & $33-50 \mathrm{~d}-3$ & & & & & $\mathrm{RM}_{3}$ & LCA & 0.70509 & 303 & +14.3 \\
\hline \multirow[t]{3}{*}{$33-56$} & $33-56-1$ & $30-35$ & M & Early Tlamimilolpa & Higher & $\mathrm{M}_{1}$ & $\mathrm{EC}$ & 0.70523 & 147 & +15.4 \\
\hline & $33-56-2^{\mathrm{a}}$ & & & & & $\mathrm{LC}_{1}$ & $\mathrm{EC}$ & - & - & +15.5 \\
\hline & $33-56-3$ & & & & & $\mathrm{M}^{3}$ & LCA & 0.70500 & 332 & +15.3 \\
\hline
\end{tabular}




\begin{tabular}{|c|c|c|c|c|c|c|}
\hline \multirow{6}{*}{ 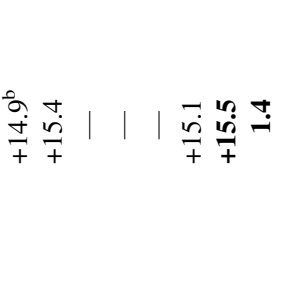 } & \multirow{5}{*}{ 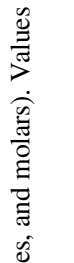 } & \multicolumn{5}{|c|}{ Table 2. Summary of Demographic Totals and Percentages. } \\
\hline & & Group & Local & Migrant & Total & $\%$ Migrant \\
\hline & & Strontium isotopes & 11 & 7 & 18 & 39 \\
\hline & & Oxygen isotopes & 7 & 7 & 14 & 50 \\
\hline & & Paired $\mathrm{Sr}$ and $\mathrm{O}$ isotopes & 13 & 10 & 23 & 43 \\
\hline & 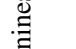 & Higher status & 4 & 7 & 11 & 64 \\
\hline \multirow{3}{*}{ ñ } & త్ర & Lower status & 9 & 3 & 12 & 25 \\
\hline & $\frac{n}{3}$ & Male & 7 & 6 & 13 & 46 \\
\hline & $\Xi$ & Female & 3 & 4 & 7 & 57 \\
\hline \multirow{4}{*}{ 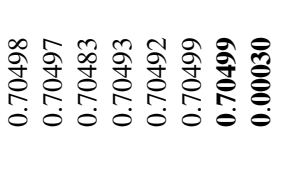 } & m & Unknown & 3 & 0 & 3 & $\mathbf{0}$ \\
\hline & $\ddot{0}$ & Tlamimilolpa & 9 & 9 & 18 & $39^{\mathrm{a}}$ \\
\hline & 焉 & Xolalpan & 1 & 2 & 3 & $9^{\mathbf{a}}$ \\
\hline & 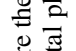 & Unknown & 2 & 0 & 2 & $0^{a}$ \\
\hline \multirow{4}{*}{ ن } & 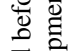 & Lapidary (AD 200-350) & 3 & 8 & 11 & $35^{\mathrm{a}}$ \\
\hline & $\overline{0} \frac{0}{0}$ & Transition (AD 300-450) & 6 & 1 & 7 & $4^{a}$ \\
\hline & $\frac{0}{2}$ & San Martín (AD 400-550) & 1 & 2 & 3 & $9^{a}$ \\
\hline & ठ & Unknown & 2 & 0 & 2 & $\mathbf{0}^{\mathbf{a}}$ \\
\hline
\end{tabular}

${ }^{\text {a }}$ Percentage $=[\#$ of migrants $] /[$ total sample $]$. Total sample $=$ 23.

oxygen isotope results indicate that 10 individuals have both or either ${ }^{87} \mathrm{Sr} /{ }^{86} \mathrm{Sr}$ ratios or $\delta^{18} \mathrm{O}_{p}$ values that fall outside the local isotope baselines for the Teotihuacan Valley (also see Table 2).

Strontium Isotopes. ${ }^{87} \mathrm{Sr} /{ }^{86} \mathrm{Sr}$ ratios for tooth enamel samples range from 0.70418 to 0.70570 , with a mean of $0.70499 \pm 0.00030$. Figure 3 illustrates the chronological order of the ${ }^{87} \mathrm{Sr} /{ }^{86} \mathrm{Sr}$ ratios based on the ceramic chronology of mortuary offerings and previously reported AMS ${ }^{14} \mathrm{C}$ dates (Storey et al. 2019:155). Here we see that $\sim 40 \%(n=7)$ of individuals have EC enamel ${ }^{87} \mathrm{Sr} /{ }^{86} \mathrm{Sr}$ ratios indicative of migrants from outside the Teotihuacan Valley (Burials 33-56, 33-14, 33-15, 33-43, 33-25, 33-50d, and 33-50b; Table 2). Burials 33-56 and 33-15 have similar LCA enamel ${ }^{87} \mathrm{Sr} /{ }^{86} \mathrm{Sr}$ ratios, suggesting residential mobility by late childhood $(0.70500$ and 0.70498 , respectively). Both of these individuals likely originated near the Basin of Mexico (see Pacheco-Forés et al. 2020). Burials 33-25 and 33-50b have a second EC enamel ${ }^{87} \mathrm{Sr} /{ }^{86} \mathrm{Sr}$ ratio that indicates movement into the region during early childhood years. Various forms of evidence suggest that both individuals came from Michoacán in west 


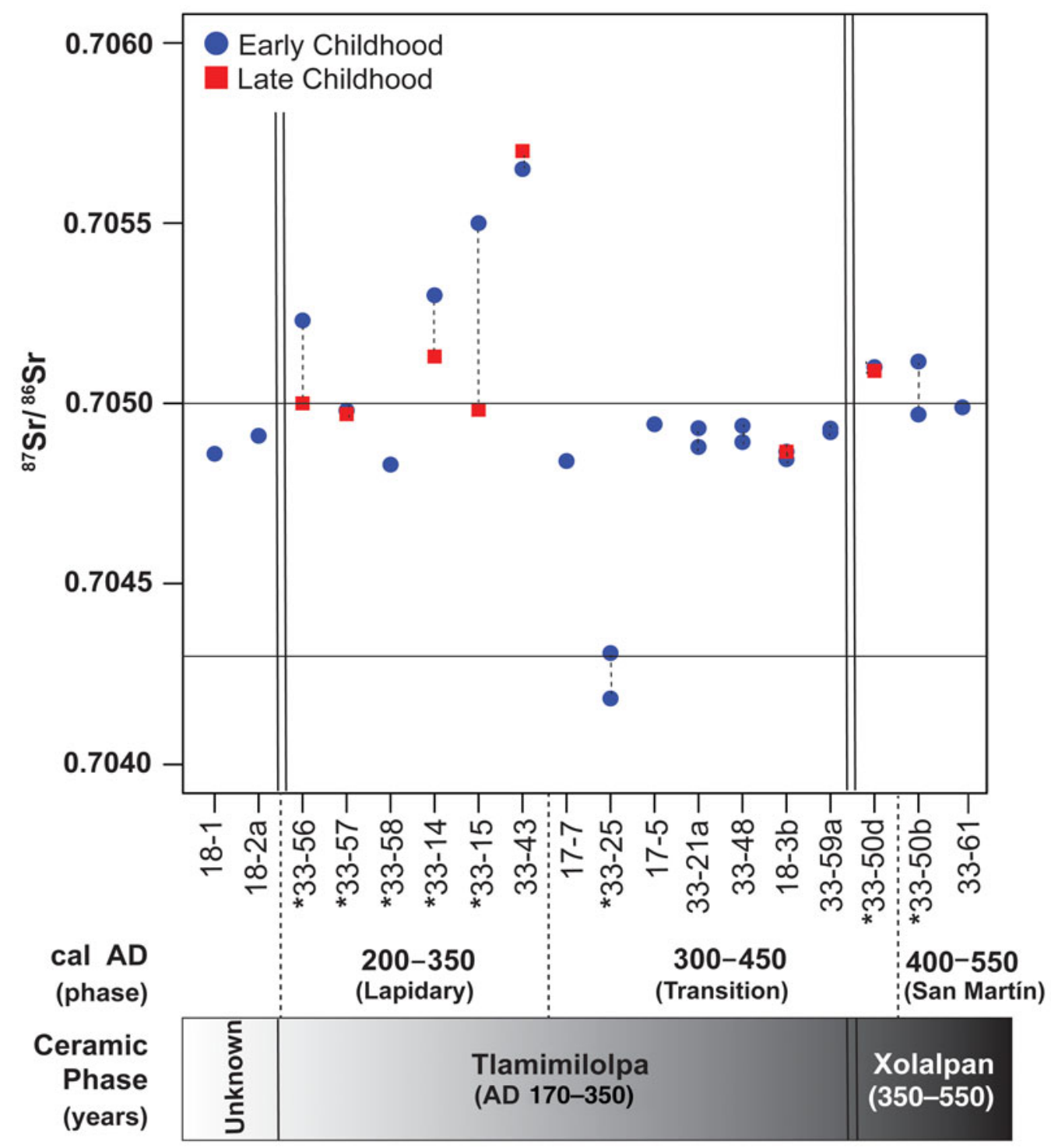

Figure 3. Chronological representations of individual ${ }^{87} \mathrm{Sr} /{ }^{86} \mathrm{Sr}$ ratios for all samples in this study. Vertical, dotted lines join multiple enamel samples for the same individual. (*) indicates higher-status individuals. The AMS ${ }^{14} \mathrm{C}$ dates were taken from Storey and colleagues (2019:155) and are reported in calibrated years AD.

Mexico. Burial 33-25 has low ${ }^{87} \mathrm{Sr} /{ }^{86} \mathrm{Sr}$ ratios consistent with this region, ranging from 0.7040 to 0.7048 (Juarez 2008; White et al. 2007:163). Burial 33-50b has a much higher $\mathrm{EC}{ }^{87} \mathrm{Sr} /{ }^{86} \mathrm{Sr}$ ratio $(0.70512)$ but was interred in a shaft tomb unlike any other at Tlajinga but that was common to west Mexico (Widmer 1987).

Burials 33-43 and 33-50d each have EC and LCA ${ }^{87} \mathrm{Sr} /{ }^{86} \mathrm{Sr}$ ratios that are nearly identical, suggesting that these individuals did not move into the Teotihuacan region before adolescence (Table 1). The ${ }^{87} \mathrm{Sr} /{ }^{86} \mathrm{Sr}$ ratios for Burial $33-43$ indicate an origin outside the central Highlands (White et al. 2007:163). Burial 33-50d, interred in the shaft tomb with $33-50 \mathrm{~b}$, does not have ${ }^{87} \mathrm{Sr} /{ }^{86} \mathrm{Sr}$ ratios that support in-migration from west Mexico. Burial 33-14 has an LCA ${ }^{87} \mathrm{Sr} /{ }^{86} \mathrm{Sr}$ ratio $(0.70513)$ lower than the EC ratio $(0.70530)$, which suggests an origin from 
within the central Highlands. This Sr-isotope composition may represent a mixing of foods consumed from both the place of origin and the Teotihuacan Valley, thus suggesting relocation of this individual during tooth enamel crown formation of the third molar.

All seven outlier individuals except for Burial 33-43 have been classified as higher status based on their burial contexts and mortuary offerings (Storey 1992). This result supports White, Storey, and colleagues' (2004) hypothesis that higher-status individuals were more likely to have immigrated from outside of Teotihuacan than those of lower status (see also Table 2). Furthermore, Burial 33-57, interpreted as a master artisan, is the only individual defined as a possible compound leader, with local ${ }^{87} \mathrm{Sr} /{ }^{86} \mathrm{Sr}$ ratios for both childhood phases (others include 33-56, 33-25, 33-50d, and 33-50b; Widmer and Storey 2012). This finding has two implications. First, it suggests that master artisans were essential members of Tlajinga society and that status was obtained through skilled craft specialization in this district. Second, it appears that compound leaders and higher-status members of Tlajinga were of both native and migrant origin, thus suggesting that all members of society could achieve a higher ranking within the social order. Outsiders, or those born outside of Teotihuacan, were not prevented from becoming more affluent members of society.

Chronologically, the highest number of individuals with nonlocal ${ }^{87} \mathrm{Sr} /{ }^{86} \mathrm{Sr}$ ratios $(n=5)$ occurs during the Tlamimilolpa phase (Figure 3 ). However, this result may be explained by discrepancies in sample size (Tlamimilolpa $=13$; Xolalpan $=3$, respectively). Of these individuals, Burial 33-25 dates to cal AD 315-395 (2 $\sigma$; Storey et al. 2019), representing the transition period between the Tlamimilolpa and Xolalpan phases, as well as the transition between lapidary and San Martín production. When observing these individuals by ${ }^{14} \mathrm{C}$ phases, we also note that the earliest ${ }^{14} \mathrm{C}$ time range, the lapidary phase, has the highest number of migrants $(n=4)$.

Oxygen Isotopes. Oxygen isotope results range from +11.3 to $+18.1 \%$, with a mean of $+15.4 \pm 1.4 \%$. Figure 4 displays the chronological order of $\delta^{18} \mathrm{O}_{p}$ values based on previously reported ceramic mortuary offerings and AMS
${ }^{14} \mathrm{C}$ dates (Storey et al. 2019:155). Here, 50\% $(n=7)$ have enamel compositions that are outside the local $\delta^{18} \mathrm{O}_{p}$ baseline for Teotihuacan (Burials 33-6, 33-14, 33-43, 33-44, 33-45a, 33-50d, and 33-50b; see also Table 2).

Burials 33-6, 33-14, and 33-43 all have LCA enamel $\delta^{18} \mathrm{O}_{p}$ values that fall outside the local baseline (Table 1). It is not clear from the $\delta^{18} \mathrm{O}_{p}$ values alone whether these individuals were born outside the region, given the lack of an EC enamel sample. For instance, 33-50b, interred in the shaft tomb, has an $\mathrm{EC} \delta^{18} \mathrm{O}_{p}$ value within the local range of variation for Teotihuacan $(+14.7 \%)$, although it should be noted that these values also coincide with local $\delta^{18} \mathrm{O}_{p}$ ranges at Michoacán (White et al. 2007:163). However, the LCA $\delta^{18} \mathrm{O}_{p}$ value from the same individual indicates possible movement outside this region (+17.2\%o). Burial 33-50b may have been born in Teotihuacan, moved during childhood, and then returned in his adult years. Or, he may have been born in west Mexico, moved outside of the central Highlands, and then arrived at Teotihuacan as an adult. Burial 50d, also interred in the shaft tomb, seems to have had a different life trajectory. The $\delta^{18} \mathrm{O}_{p}$ signatures from EC (+16.3\%o) and LCA $(+17.3 \%$ ) suggest that 33-50d was born and lived outside the city for the majority of his childhood (White et al. 2007:163). By early adolescence, his third molar had acquired a lower $\delta^{18} \mathrm{O}_{p}$ value $(+14.3 \%)$, indicating his eventual move into Teotihuacan or, plausibly, Michoacán. If the latter is true, he may have arrived in Tlajinga as an adult, similar to 33-50b with whom he was buried.

Chronological observations of the $\delta^{18} \mathrm{O}_{p}$ data show that the highest number of nonlocal individuals occur in the Tlamimilolpa sample $(n=5$; Figure 4). As with the ${ }^{87} \mathrm{Sr} /{ }^{86} \mathrm{Sr}$ data, this finding may not be representative of both time periods, given that the Tlamimilolpa sample is much larger than the Xolalpan ( $n=11$ and 3, respectively). Here, the lapidary group is also considerably larger than the other two ${ }^{14} \mathrm{C}$ phase groups ( $n=10,2$, and 2, respectively). Nevertheless, it is noteworthy that many migrants fall along the transitional points between the Tlamimilolpa and Xolalpan ceramic phases and across the transitions between the three ${ }^{14} \mathrm{C}$ phase groups (Figure 4). 


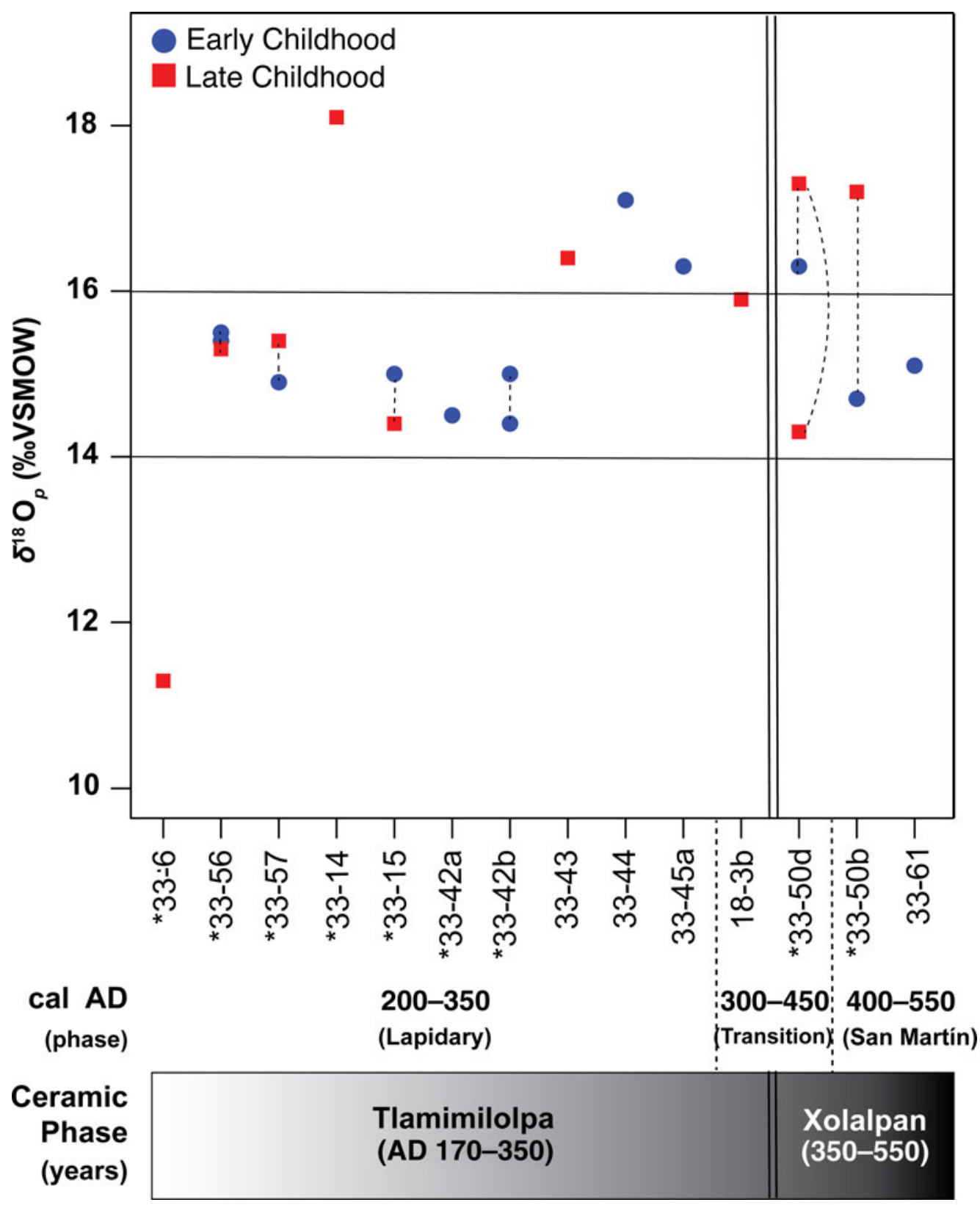

Figure 4. Chronological representations of individual $\delta^{18} \mathrm{O}_{p}$ values for all samples in this study. Vertical, dotted lines join multiple enamel samples for the same individual. $(*)$ indicates higher-status individuals. The AMS ${ }^{14} \mathrm{C}$ dates were taken from Storey and colleagues (2019:155) and are reported in calibrated years AD.

Overall, we conclude that, of the 23 individuals in this study, $\sim 45 \%(n=10)$ were migrants from outside Teotihuacan (Burials 33-6, 33-14, $33-15$, 33-25, 33-43, 33-44, 33-45, 33-50b, $33-50 \mathrm{~d}$, and 33-56; Table 2). This proportion is higher than reported by White, Storey, and colleagues (2004), who estimated nonlocals as $\sim 30 \%$ of the Tlajinga 33 population using a similar sample size. All migrants identified thus far come from Tlajinga 33, but the sample from Tlajinga 17 and 18 is too small to determine whether only local individuals resided there. 


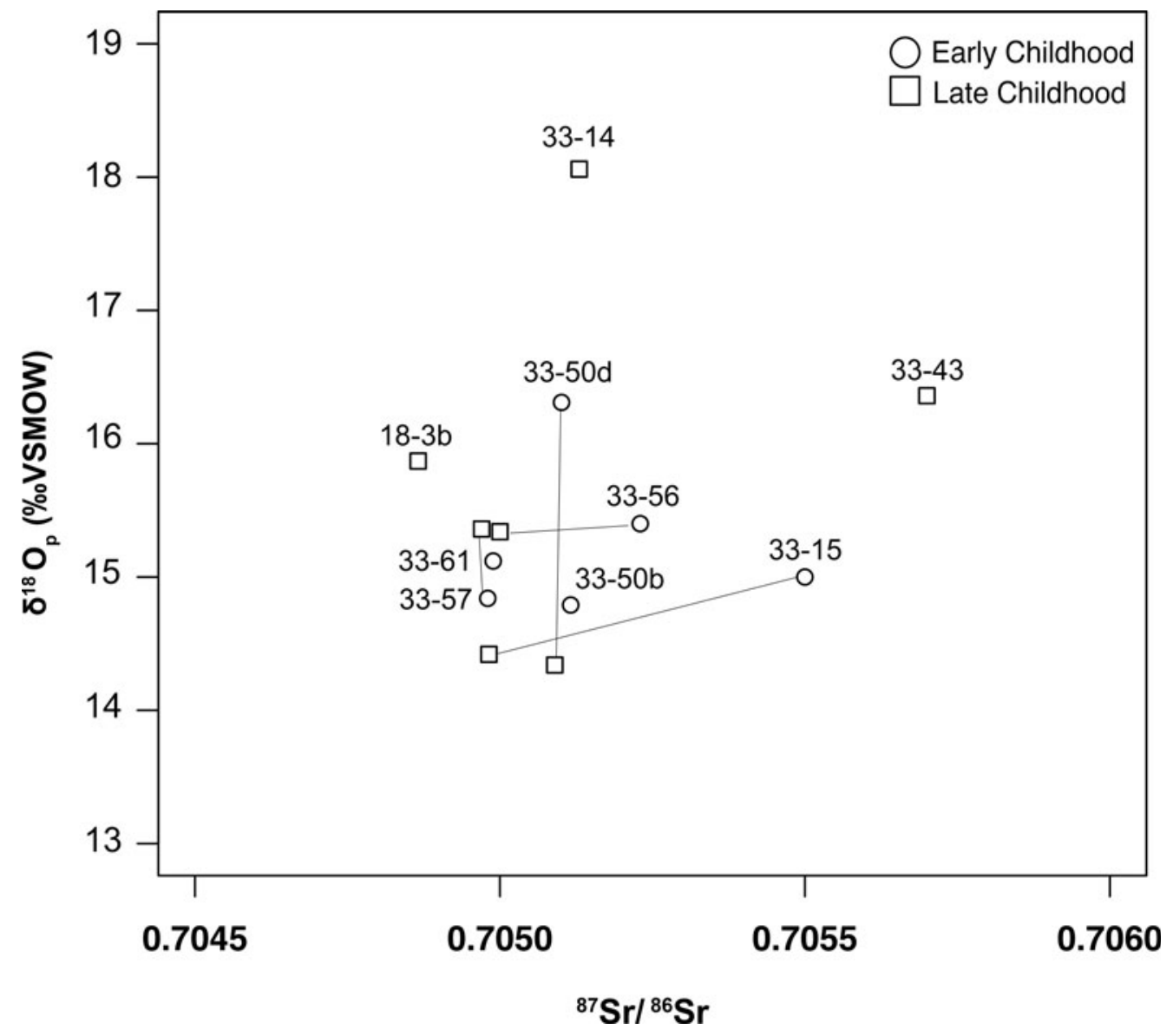

Figure 5. Biplot of ${ }^{87} \mathrm{Sr} /{ }^{86} \mathrm{Sr}$ and $\delta^{18} \mathrm{O}_{p}$ results. The sample ID is provided next to data points, and lines connect early and late childhood tooth enamel samples from the same individual.

Dual-Isotope Approach. Figure 5 illustrates the covariation of tooth enamel Sr- and O-isotope compositions for the nine individuals for whom both isotopic systems were analyzed. We used hierarchical cluster analysis to determine significant groupings among individuals and to identify potential in-migration patterns from similar points of origin. This analysis showed that the optimal number of clusters in this sample set was only two (Figure 6) and that the two-cluster model produced the most significant results (Supplemental Table 2a).

The first cluster comprises the majority of individuals analyzed for both $\mathrm{Sr}$ and $\mathrm{O}$ isotopic compositions $(n=6)$, with an ${ }^{87} \mathrm{Sr} /{ }^{86} \mathrm{Sr}$ range of 0.70487 to 0.70523 (mean $=0.70503 \pm 0.00010$, $1 \sigma)$ and a $\delta^{18} \mathrm{O}_{p}$ range of +14.3 to $+15.9 \%$ (mean $=+15.2 \pm 0.6 \%$ o, $1 \sigma)$. This cluster contains those individuals with isotopic signatures significantly similar to those in the Teotihuacan Valley. However, this result does not indicate that all individuals in the first cluster are those native to Teotihuacan, but rather that they are from isotopically similar regions. For example, individuals from the greater Basin of Mexico but outside the Teotihuacan Valley would be included in this grouping (see Pacheco-Forés et al. 2020).

The second cluster includes samples from three individuals with an ${ }^{87} \mathrm{Sr} /{ }^{86} \mathrm{Sr}$ range of 0.70513 to 0.70570 (mean $=0.70544 \pm 0.00029$, $1 \sigma)$ and a $\delta^{18} \mathrm{O}_{p}$ range of +15.0 to $+18.1 \%$ $($ mean $=+16.5 \pm 1.6 \%$ o, $1 \sigma)$. Rather than a true "cluster" of isotopically similar individuals, this second group consists of distinct entities, all of which are the farthest-outlying isotopic 


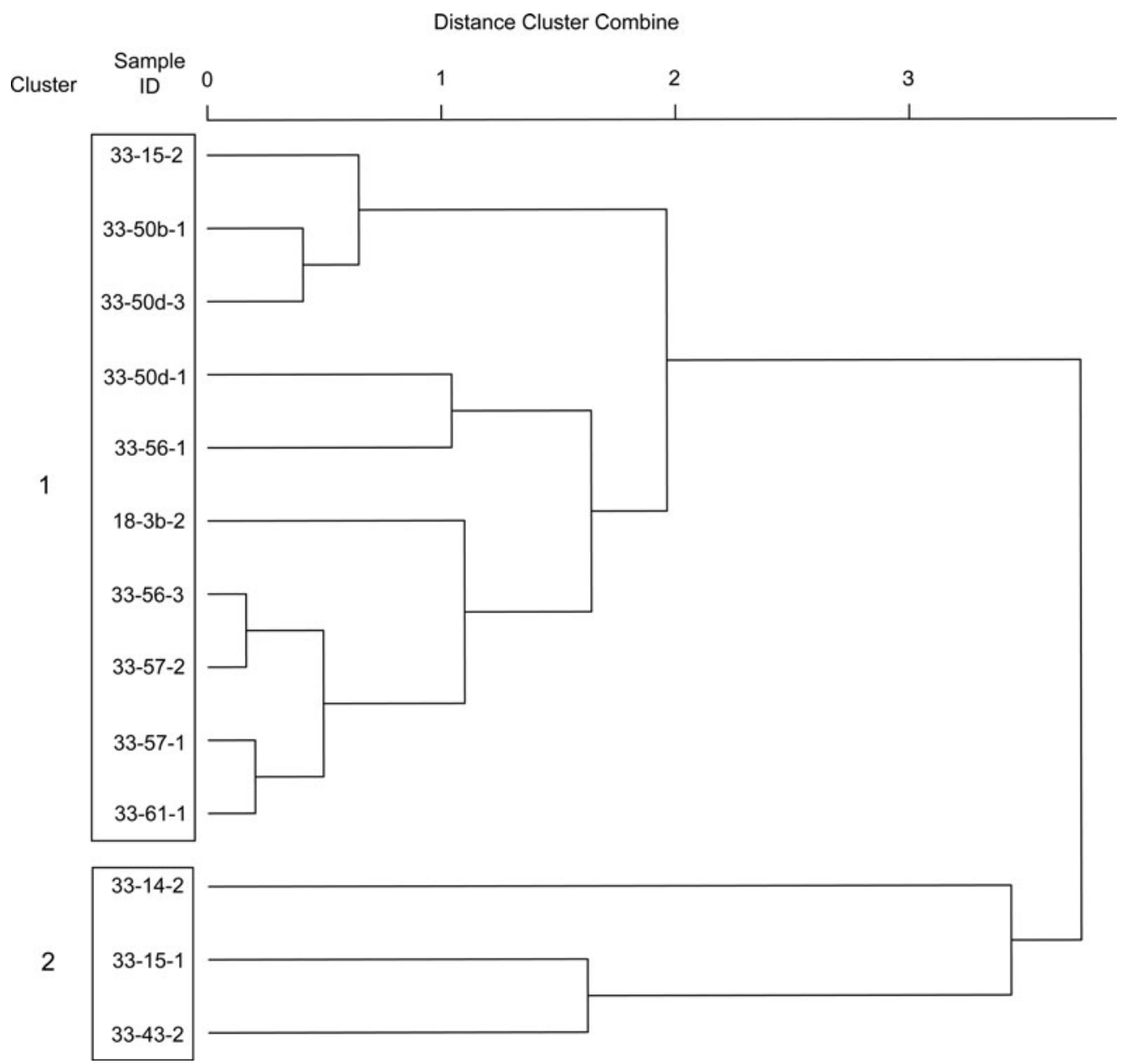

Figure 6. Hierarchical cluster analysis results. The dendrogram displays the average linkage between groups based on $\mathrm{Sr}$ and $\mathrm{O}$ isotope parameters for all individuals undergoing both analytical procedures $(n=9)$.

signatures in the sample set compared to the local Teotihuacan baselines. For example, Burial 33-14 has the highest $\delta^{18} \mathrm{O}_{p}$ value $(+18.1 \%$ ) but only slightly higher-than-local ${ }^{87} \mathrm{Sr} /{ }^{86} \mathrm{Sr}$ ratios $(0.70530,0.70513)$. As discussed earlier, the ${ }^{87} \mathrm{Sr} /{ }^{86} \mathrm{Sr}$ ratios for $33-14$ suggest origins from within the central Highlands. However, the $\delta^{18} \mathrm{O}_{p}$ value is too high for this region, and the combined isotopic compositions best match a possible origin in the southern Highlands near Kaminaljuyu (White et al. 2007:163). In contrast, Burial 33-43 has the highest ${ }^{87} \mathrm{Sr} /{ }^{86} \mathrm{Sr}$ ratios $(0.70565,0.70570)$ but is only slightly enriched in ${ }^{18} \mathrm{O}$ relative to the local baseline $\left(\delta^{18} \mathrm{O}_{p}=+16.4 \%\right.$ ), making it unclear where he was born. For Burial 33-15, we see a significant difference between early and late childhood isotopic compositions. Although the $\mathrm{EC}{ }^{87} \mathrm{Sr} /{ }^{86} \mathrm{Sr}$ ratio lies outside the local baseline (0.70550), the $\delta^{18} \mathrm{O}_{p}$ value is within the local range of variation $(+15.0 \%)$. The $\mathrm{LCA}{ }^{87} \mathrm{Sr} /{ }^{86} \mathrm{Sr}$ ratio then decreases to a local value ( 0.70498$)$, thus indicating a significant change in the geological provenance of the food resources available to her; this ratio falls within Cluster 1. Likely, this individual was born within the central Highlands and moved into Teotihuacan by adolescence.

When attempting to connect migrants to their region of origin in Mesoamerica, a complicating factor is that multiple regions can present similar isotopic compositions. This is particularly true for Teotihuacan and Michoacán, which have 
overlapping ${ }^{87} \mathrm{Sr} /{ }^{86} \mathrm{Sr}$ and $\delta^{18} \mathrm{O}_{p}$ baselines. These similar isotopic signatures complicate the interpretation of isotopic data given that material evidence of migration from west Mexico is prevalent across all Tlajinga compounds. Along with the shaft tomb at Tlajinga 33, clay figurines with stylistic attributes from west Mexico were found at Tlajinga 17 and 18 (Carballo et al. 2019:Figure 14j). Furthermore, there is a need to expand the mapping of isotopic compositions across all of Mesoamerica; the baselines currently available are few and far between (see Hodell et al. 2004; Pacheco-Forés et al. 2020). Therefore, we exercise caution when attempting to pinpoint origins for outlier individuals based solely on isotopic data and without multiple lines of evidence.

\section{Patterns of Migration among Demographic Groups}

This study tested for significant differences between residential and demographic groups to identify specific groups of people who migrated to Tlajinga. As stated earlier, these groups are divided according to time phases (ceramic and ${ }^{14} \mathrm{C}$ dating), compound, status, and sex. Obtaining meaningful results is challenging in a study with such a small sample size. Therefore, we assess these results with caution, and in this section, we discuss only those tests with significant differences between group means $(p<0.05)$. Only the tests involving ${ }^{87} \mathrm{Sr} /{ }^{86} \mathrm{Sr}$ group means are significant. Complete results for all statistical tests are provided in Supplemental Tables 2b-e.

For all tooth enamel samples, there is no difference in the mean ${ }^{87} \mathrm{Sr} /{ }^{86} \mathrm{Sr}$ ratio of $23 \mathrm{EC}$ and 7 LCA enamel specimens (Mann-Whitney $U ; W=48, p=0.12$ ), nor is there a difference in the mean $\delta^{18} \mathrm{O}_{p}$ signatures of $12 \mathrm{EC}$ and 9 LCA samples (Student $t$-test; $t=0.014, d f=19$, $p=0.99$ ). Therefore, data from both developmental phases can be considered together for statistical purposes. However, we provide statistical analysis of demographic groups and tooth development phases in Supplemental Table 2b.

We tested for differences in ${ }^{87} \mathrm{Sr} /{ }^{86} \mathrm{Sr}$ group means between Tlajinga $33(n=24)$ and Tlajinga 17 and 18 (combined due to small sample size, $n=6$ ). The $\delta^{18} \mathrm{O}_{p}$ sample size is too small for statistical analysis. Tlajinga 17 and 18 have a narrow range of ${ }^{87} \mathrm{Sr} /{ }^{86} \mathrm{Sr}$ ratios compared to the broader range for Tlajinga 33, although this is likely due to the small sample size (Figure 7a). A Mann-Whitney $U$ test indicates that ${ }^{87} \mathrm{Sr} /{ }^{86} \mathrm{Sr}$ group means are significantly different $(W=118, p=0.02$; see Supplemental Table 2c): Tlajinga 33 has a higher ${ }^{87} \mathrm{Sr} /{ }^{86} \mathrm{Sr}$ mean than Tlajinga 17 and 18 by 0.00032 on average. These data suggest that residents of Tlajinga 33 were eating foods with slightly higher ${ }^{87} \mathrm{Sr} /{ }^{86} \mathrm{Sr}$ ratios.

A previous examination of diet using stable carbon isotopes found that residents of Tlajinga 33 were slightly more reliant on a maize-based diet than those at Compounds 17 and 18 (Storey et al. 2019:153-154). Mano and metate fragments were abundant at Tlajinga 33 (Widmer 1987) but less so at Tlajinga 17 and 18. Tlajinga 33 residents may have processed their maize for consumption only within this compound, but perhaps the other two residential groups obtained this staple crop from a different source, explaining the discrepancy in both strontium and carbon isotope compositions.

Across compounds, there are also significant differences between the ${ }^{87} \mathrm{Sr} /{ }^{86} \mathrm{Sr}$ means of Tlajinga 33 males (0.70516), Tlajinga 17-18 males (0.70488), and Tlajinga 17-18 females (0.70487; Supplemental Tables 2d-e). However, Tlajinga 33 females $(n=7)$, many of whom have nonlocal ${ }^{87} \mathrm{Sr} /{ }^{86} \mathrm{Sr}$ ratios, have a broader range of signatures than those measured for males $(n=$ 11; Figure 7a). For example, $57 \%$ of women in this study were migrants, based on their ${ }^{87} \mathrm{Sr} /{ }^{86} \mathrm{Sr}$ and $\delta^{18} \mathrm{O}_{p}$ signatures (Table 2). Male migrants, by comparison, constitute $46 \%$ of the total male population.

Of the females with nonlocal isotopic compositions, all are also of higher status $(n=4$; Burials 33-6, 33-14, 33-15, and 33-25). These data may indicate that women of prestige migrated into Tlajinga after tooth development was complete, perhaps for marriage or childbearing. Returning to the original hypothesis that poor health conditions would have required a constant influx of migrants, it is plausible that women were recruited from outside the city for reproductive purposes and to maintain the population over time. Given that this would have been an immense responsibility, these women may have 
(a)
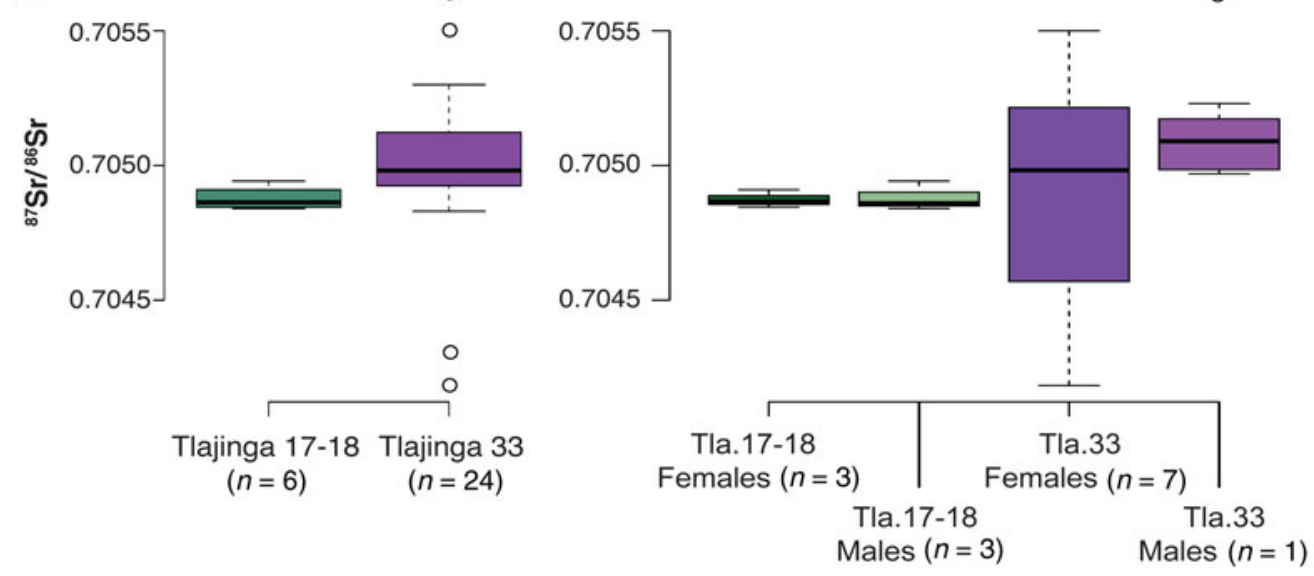

(b)
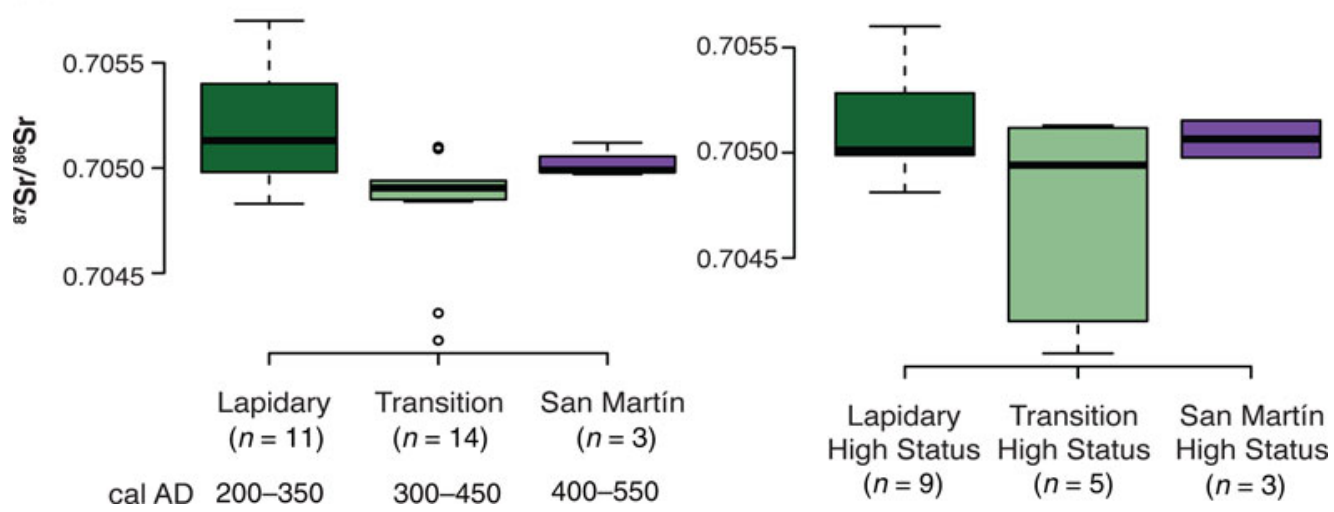

Figure 7. (a) The distribution of ${ }^{87} \mathrm{Sr} /{ }^{86} \mathrm{Sr}$ ratios by compound (left) and by sex and compound (right). "Tla" = Tlajinga. (b) The distribution of ${ }^{87} \mathrm{Sr} /{ }^{86} \mathrm{Sr}$ ratios by ${ }^{14} \mathrm{C}$ date phases for all samples (left) and by ${ }^{14} \mathrm{C}$ date phase and status (right).

been revered after death, as demonstrated by the more elaborate burial offerings present in the archaeological record. More pragmatically, migrant women probably had larger families than local women because of the malnutrition common among native residents. The offspring of nonlocal women represented a larger portion of the population in subsequent generations and, thereby, a larger number of individuals contributing to the compound economy. Perhaps, the sheer number of offspring memorializing the graves of nonlocal women is the reason why these mortuary remains appear to be of higher status than those of local women.

A similar pattern of female paleomobility has been noted in the Oaxaca Barrio, a Teotihuacan enclave of Zapotec immigrants. Here, the $\delta^{18} \mathrm{O}_{p}$ of bone and tooth enamel suggests that women were sojourning from various diasporic nodes while breastfeeding (White, Spence, et al. 2004); it is hypothesized that this movement was essential to the sociopolitical construction and maintenance of Zapotec identity among new generations while living outside the Oaxaca homeland.

It is difficult to make comparisons between children in these two neighborhoods, because the two young individuals from the present Tlajinga sample, 33-21a and 33-59a, are not connected to any of the female burials. However, the ${ }^{87} \mathrm{Sr} /{ }^{86} \mathrm{Sr}$ ratios of the Tlajinga children do not suggest movement in early life but instead support local birth. These observations represent a significant social distinction between Tlajinga and the Oaxaca Barrio. Although it is clear that the people of the Oaxaca Barrio were motivated 
to retain their ethnic identity while living in Teotihuacan, the migrants of Tlajinga appear to have assimilated almost entirely to the local social and political norms. This conformation to Teotihuacan identity was perhaps driven by the large-scale participation of Tlajinga residents in crafting and manufacturing local goods for distribution across the city. Storey (1992) also suggests that singular individuals or small families migrated into Tlajinga, whereas the Oaxaca Barrio likely experienced migration en masse. Therefore, it would have been much easier for the people of Tlajinga to assimilate to local Teotihuacan customs rather than hold onto practices from their homelands.

Time phases by ceramic chronological groups (Tlamimilolpa and Xolalpan) show no significance between either ${ }^{87} \mathrm{Sr} /{ }^{86} \mathrm{Sr}$ or $\delta^{18} \mathrm{O}_{p}$ group means. Nevertheless, time phases classified by ${ }^{14} \mathrm{C}$ date ranges do have significant differences (Supplemental Tables 2c and 2e): the lapidary phase mean ${ }^{87} \mathrm{Sr} /{ }^{86} \mathrm{Sr}$ ratio $(0.70521 ; n=11)$ is significantly different from the transition phase mean $(0.70483 ; n=14)$. However, there is no significant difference between the San Martín phase mean (0.70503) and the lapidary or transition means. These results likely stem from the fact that the San Martín phase consists of only three samples. Results confirm earlier observations that individuals with ${ }^{87} \mathrm{Sr} /{ }^{86} \mathrm{Sr}$ ratios significantly higher than the local Teotihuacan baseline are most common at Tlajinga during the first phase of compound occupation (Figure 7b).

For mean ${ }^{87} \mathrm{Sr} /{ }^{86} \mathrm{Sr}$, the lapidary and transition phases are also significantly different between status groups and sex and within the Tlajinga $33 \mathrm{com}$ pound (Supplemental Tables $2 \mathrm{~d}-\mathrm{e}$ ). The sample size for Tlajinga 17-18 was too small for comparison $(n=4)$. The mean ${ }^{87} \mathrm{Sr} /{ }^{86} \mathrm{Sr}$ ratio $(0.70510, n=9)$ for all higher-status interments in the lapidary phase is significantly higher than the transition-phase mean $(0.70472, n=5$; Figure $7 \mathrm{~b}$ ), although this is mostly a reflection of Burial 33-25's low ratios. Additionally, females $(0.70515, n=5)$ and males $(0.70526, n=6)$ in the lapidary phase also have higher mean ${ }^{87} \mathrm{Sr} /{ }^{86} \mathrm{Sr}$ ratios than transition-phase females $(0.70455$, $n=4$ ), also due to Burial 33-25.

Combing the ${ }^{87} \mathrm{Sr} /{ }^{86} \mathrm{Sr}$ and $\delta^{18} \mathrm{O}_{p}$ data, we see that during the Tlamimilolpa phase, $39 \%$ of the sample population were migrants compared to 9\% during the Xolalpan (Table 2). The same is true for the ${ }^{14} \mathrm{C}$ date phases. During the lapidary phase, $35 \%$ of the sample population have nonlocal isotopic signatures, but only $4 \%$ are nonlocal during the transition phase and $9 \%$ during the San Martín phase. Therefore, we conclude that migration was highest during the first centuries of compound occupation. However, migration did not end after this point but continued at a lower rate. Additionally, $\sim 65 \%$ of higher-status individuals were migrants compared to only $25 \%$ of lower-status people, although mean ${ }^{87} \mathrm{Sr} /{ }^{86} \mathrm{Sr}$ ratios and $\delta^{18} \mathrm{O}_{p}$ values were not significantly different between the groups.

\section{Nixtamalization and Strontium Isotopes}

Although our confidence in the isotopic results presented here is high, it is important to note an anomaly in the Tlajinga Sr-isotope data. The range of ${ }^{87} \mathrm{Sr} /{ }^{86} \mathrm{Sr}$ ratios for the Teotihuacan Valley lies between 0.7043 and 0.7050 , yet most of the samples used to define this baseline are between 0.7043 and 0.7048 , with only one sample having a higher value (see Supplemental Table 1). Therefore, the Sr-isotope signatures of tooth enamel from local individuals, which vary between 0.7048 and 0.7050 , plot above the majority of the samples defining the baseline (Figure 8). Instead, we would expect to see the ${ }^{87} \mathrm{Sr} /{ }^{86} \mathrm{Sr}$ ratios distributed about the entire local baseline from 0.7043 to 0.7050 . These data, however, suggest that some strontium in the diet comes from an additional source with different ${ }^{87} \mathrm{Sr} /{ }^{86} \mathrm{Sr}$ ratios. In Figure 8, we also see that local individuals have higher $\mathrm{Sr}$ concentrations (ppm) than migrants. Depending on the identification of a clear mixing line (Montgomery et al. 2010), higher Sr ppm will potentially support an additional source of strontium in the diet. A possible explanation for this discrepancy could be the incorporation of strontium into the local diet via nixtamalization.

Nixtamalization - the process of adding an alkali solution of lime or wood ash to maize to enhance the nutritional value of this staple dish -was practiced across Mesoamerica (Katz et al. 1974). Wright (2012:339) suggested that alkaline processing using lime be considered the primary 


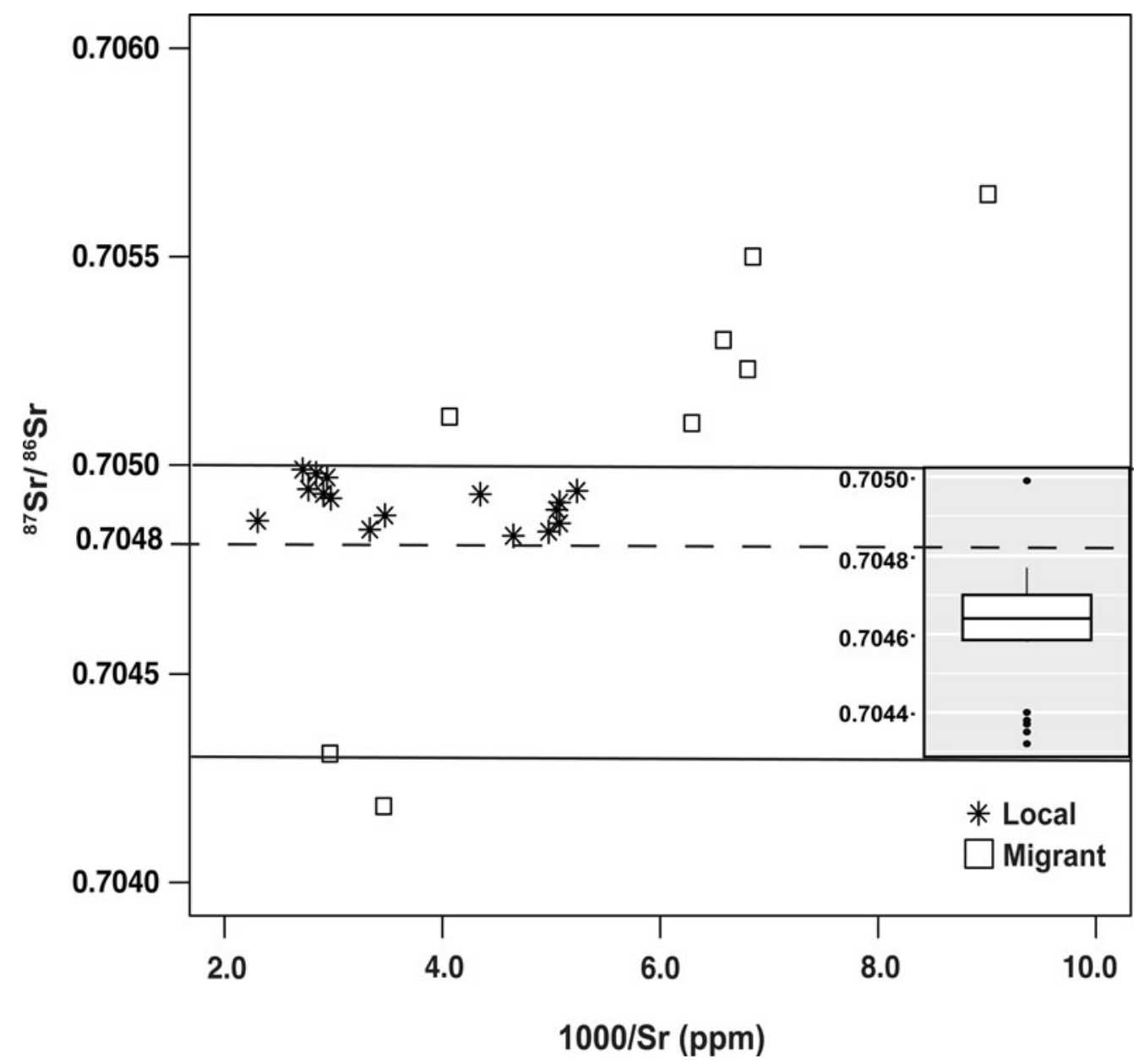

Figure 8. Measurements of ${ }^{87} \mathrm{Sr} /{ }^{86} \mathrm{Sr}$ ratios and $\mathrm{Sr}$ concentrations $(1000 / \mathrm{Sr})$ of human enamel from Tlajinga differentiated by early childhood measurements for local (asterisks) and migrant (squares) individuals as determined by this study. The horizontal lines represent the range of variation representative for the ${ }^{87} \mathrm{Sr} /{ }^{86} \mathrm{Sr}$ ratios in the local environmental. The dashed line represents the upper value for the local range when the anomalous water sample measured for this study is removed. Inset: Boxplot of all samples in this study used to develop the ${ }^{87} \mathrm{Sr} /{ }^{86} \mathrm{Sr}$ baseline range for the Teotihuacan Valley.

source of strontium in human remains from the Maya region, because at least $50 \%$ of the diet was maize. Additionally, the impact of the alkali solution used for nixtamalization on the ${ }^{87} \mathrm{Sr} /{ }^{86} \mathrm{Sr}$ signatures of maize consumers in the Classic period Soconusco region has also been suggested (Renson et al. 2019). As discussed earlier, the stable carbon isotope ratios obtained for Tlajinga individuals show that the diet here was maize-dominant (Storey et al. 2019; White, Storey, et al. 2004). There is also good evidence from Teotihuacan that lime was primarily used for maize preparation (Biskowski 2017).
Lime can be derived from limestone or shells. Although no limestone was locally accessible in the Teotihuacan Valley, 12 million square meters of architectural surfaces across the city were covered with mortar and plaster made from a lime solution (Barba and Frunz 1999). Biskowski (2017:32) states that the amount of lime required for nixtamalization would have been negligible compared to that needed for construction. Therefore, the limestone source used at Teotihuacan for nixtamalization could derive from the same limestone source used for construction materials. 
The closest limestone source was in the Zumpago region in the Basin of Mexico, approximately $40 \mathrm{~km}$ northwest of Teotihuacan. Nevertheless, no evidence thus far suggests Teotihuacan was importing from this location (Murakami et al. 2013). Barba and colleagues (2009) analyzed lime plaster from Teopancazco, a Teotihuacan apartment compound, and found that it came from the Tula region, $60 \mathrm{~km}$ northwest of Teotihuacan in the state of Hidalgo. Transportation from Chingú to Teotihuacan would take one day on foot (Carballo 2013:Figures 5.8 and 5.9), a reasonable distance for a population with no wheel technology or beasts of burden. Additional research by Murakami and colleagues (2013) suggests that in the later years of Teotihuacan occupation the Tepeaca region in the state of Puebla, nearly $150 \mathrm{~km}$ to the east of Teotihuacan, was another source of limestone for the city.

Limestone from both of these sources was formed during the Cretaceous and Jurassic periods and have expected $\mathrm{Sr}$-isotope ratios between $\sim 0.7068$ and $\sim 0.7078$, derived from the ${ }^{87} \mathrm{Sr} /{ }^{86} \mathrm{Sr}$ evolution curve for seawater through geological time (Richter et al. 1992). This range is much higher than our estimated ${ }^{87} \mathrm{Sr} /{ }^{86} \mathrm{Sr}$ ratios for the Teotihuacan Valley (0.7043-0.7050), which is surrounded by Cenozoic volcanic rocks. Therefore, we hypothesize that the addition of an alkali solution made from any of these sources of limestone to the Teotihuacano diet could have caused an upward shift in the measured Sr-ratios.

Further research and comparisons to other populations within and outside of Teotihuacan need to be conducted to confirm this hypothesis. Given that nixtamalization was a common practice across Mesoamerica, it may also be a factor in the measured ${ }^{87} \mathrm{Sr} /{ }^{86} \mathrm{Sr}$ of migrants. Unless migrant individuals were ingesting lime from geological sources local to their diets, their ${ }^{87} \mathrm{Sr} /{ }^{86} \mathrm{Sr}$ signatures are also likely skewed.

Additional discussion of nixtamalization and of its possible effect on the interpretation of Sr-isotope ratios is beyond the scope of this article. That said, further investigation of this hypothesis at Teotihuacan and other sites in Mesoamerica is an important avenue for future $\mathrm{Sr}$-isotope studies.

\section{Conclusions}

Applying a dual-isotope approach $\left({ }^{87} \mathrm{Sr} /{ }^{86} \mathrm{Sr}\right.$ and $\delta^{18} \mathrm{O}_{p}$ ) to human tooth enamel from three apartment compounds in the Tlajinga district, we find that migrants comprised $\sim 45 \%$ of the population. Our results bolster the original study of White, Storey, and colleagues (2004) that used $\delta^{18} \mathrm{O}_{p}$ values only. We also refine the range of local ${ }^{87} \mathrm{Sr} /{ }^{86} \mathrm{Sr}$ ratios $(0.7043-0.7050)$ for the Teotihuacan Valley by analyzing local faunal and water samples. The ${ }^{87} \mathrm{Sr} /{ }^{86} \mathrm{Sr}$ and $\delta^{18} \mathrm{O}_{p}$ data, along with mortuary and ceramic evidence, suggest that in-migration from Michoacán in west Mexico likely occurred at Tlajinga. However, these isotopic compositions are challenging to discern from Teotihuacan, because both isotopic systems overlap considerably between regions.

Previously reported radiocarbon dates and mortuary data reveal that in-migration was highest during the first centuries of district occupation, although the sample size for later occupation at Tlajinga is small. However, in-migration occurred throughout the history of Tlajinga and was a significant demographic process throughout neighborhood occupation.

Our results support an earlier hypothesis that higher-status individuals were inclined to have nonlocal isotope signatures; more than twice as many have nonlocal isotopic ratios than those of lower status. Additionally, the range of isotopic compositions of Tlajinga 33 females is considerably broader than in males, indicating possible recruitment of women to this compound for marriage and childbearing.

Mean ${ }^{87} \mathrm{Sr} /{ }^{86} \mathrm{Sr}$ ratios are significantly higher in Tlajinga 33 than in Tlajinga 17 and 18. We hypothesize that the importation of lime from outside Teotihuacan for nixtamalization of maize may have skewed the local human ${ }^{87} \mathrm{Sr} /{ }^{86} \mathrm{Sr}$ signatures. A higher proportion of maize consumption in the diet among Tlajinga 33 residents - consistent with previous research - could have resulted in greater exposure to imported lime, thus causing the higher ${ }^{87} \mathrm{Sr} /{ }^{86} \mathrm{Sr}$ ratios found among local individuals. Further research exploring this hypothesis is needed across Teotihuacan neighborhoods and throughout Mesoamerica. 
Acknowledgments. Material in this article was based on work supported by the U.S. National Science Foundation (NSF) Dissertation Improvement Grant (BCS-1927690) (GMB, KGH), the Proyecto Arqueológico Tlajinga Teotihuacan (PATT) funded by the NSF (BCS-13212447) (DMC, $\mathrm{KGH}$ ), and a Junior Fellowship at Dumbarton Oaks Research Library and Collection (GMB). The oxygen isotope analyses were supported in part by the Canada Research Chairs Program (FJL). Permission for destructive analysis of human remains was provided by the Instituto Nacional de Antropología e Historia in Mexico City. The Archaeometry Laboratory at University of Missouri Research Reactor is supported by the NSF (grant \#BCS-1912776), and a previous NSF grant (\#BCS-1621158) provided Gina Buckley a Graduate Internship (Virginie Renson). We are grateful for the invaluable comments from all reviewers that improved this article. Additional thanks go to Andrés Mejía Ramón for collecting water samples, Maria Codlin for fauna identification, and Grace Yau (LSIS) for assistance with the phosphate oxygen isotope analyses. This is Western's Laboratory for Stable Isotope Science Contribution \#380.

Data Availability Statement. All data presented in this article can be obtained from ScholarSphere (Penn State), https://doi. org/10.26207/483d-ve56.

Supplemental Materials. For supplemental material accompanying this article, visit https://doi.org/10.1017/laq.2021.20.

Supplemental Text 1. R Markdown Tlajinga Hierarchical Cluster Code.

Supplemental Text 2. Strontium and Oxygen Isotope Methodology.

Supplemental Table 1. Teotihuacan Valley ${ }^{87} \mathrm{Sr} /{ }^{86} \mathrm{Sr}$ Ratio Baseline Measurements.

Supplemental Tables 2a-e. Statistical Results of Hierarchal Cluster Analysis and All Significance Tests.

\section{References Cited}

Adams, Shaun, Rainer Grün, David McGahan, Jian-Xin Zhao, Yuexing Feng, Ai Nguyen, Malte Willmes, Michael Quaresimin, Brett Lobsey, Mark Collard, and Michael C. Westaway

2019 A Strontium Isoscape of North-East Australia for Human Provenance and Repatriation. Geoarchaeology 34:231-251.

Barba, Luis, Jorge Blancas, Linda R. Manzanilla, Agustin Ortiz, Donatella Barca, Gino M. Crisci, Domenico Miriello, and Alessandra Pecci

2009 Provenance of the Limestone Used in Teotihuacan (Mexico): A Methodological Approach. Archaeometry 51:525-545.

Barba, Luis A., and José Luis Córdova Frunz

1999 Estudios energéticos de la producción de cal en tiempos teotihuacanos y sus implicaciones. Latin American Antiquity 10:168-179.

Bentley, R. Alexander

2006 Strontium Isotopes from the Earth to the Archaeological Skeleton: A Review. Journal of Archaeological Method and Theory 13:135-187.
Biskowski, Martin

2017 Staple Food Preparation at Teotihuacan. Archaeological and Anthropological Sciences 9:29-38.

Carballo, David M.

2011 Advances in the Household Archaeology of Highland Mesoamerica. Journal of Archaeological Research 19:133-189.

2013 The Social Organization of Craft Production and Interregional Exchange at Teotihuacan. In Merchants, Markets, and Exchange in the Pre-Columbian World, edited by Kenneth G. Hirth and Joanne Pillsbury, pp. 113-140. Dumbarton Oaks, Washington, DC.

Carballo, David M., Kenneth G. Hirth, Daniela Hernández Sariñana, Gina M. Buckley, Andrés G. Mejía Ramón, and Douglas J. Kennett

2019 New Research at Teotihuacan's Tlajinga District, 2012-2015. Ancient Mesoamerica 30:95-113.

Clayton, Sarah C

2005 Interregional Relationships in Mesoamerica: Interpreting Maya Ceramics at Teotihuacan. Latin American Antiquity 16:427-448.

Cowgill, George L.

2015 Ancient Teotihuacan. Cambridge University Press, New York.

Gómez Chávez, Sergio

2002 Presencia del occidente de México en Teotihuacan: Aproximaciones a la política exterior del estado teotihuacano. In Ideología y política a través de materiales, imágenes y símbolos: Memoria de la Primera Mesa Redonda de Teotihuacan, edited by María Elena Ruiz, pp. 563-625. Instituto de Investigaciones Antropológicas, Instituto de Investigaciones Estéticas, UNAM, INAH, Mexico City.

Grimes, Vaughan, and Maura Pellegrini

2013 A Comparison of Pretreatment Methods for the Analysis of Phosphate Oxygen Isotope Ratios in Bioapatite. Rapid Communications in Mass Spectrometry 27:375-390.

Grimstead, Deanna N., Selin Nugent, and Jean Whipple

2017 Why a Standardization of Strontium Isotope Baseline Environmental Data Is Needed and Recommendations for Methodology. Advances in Archaeological Practice 5:184-195.

Hillson, Simon

1996 Dental Anthropology. Cambridge University Press, New York.

Hirth, Kenneth G., David M. Carballo, Mark Dennison, Sean Carr, Sarah Imfeld, and Eric Dyrdahl

2019 Excavation of an Obsidian Craft Workshop at Teotihuacan, Mexico. Ancient Mesoamerica 30:163-179.

Hodell, David A., Rhonda L. Quinn, Mark Brenner, and George Kamenov

2004 Spatial Variation of Strontium Isotopes ${ }^{87} \mathrm{Sr} /{ }^{86} \mathrm{Sr}$ in the Maya Region: A Tool for Tracking Ancient Human Migration. Journal of Archaeological Science 31:585-601.

Juarez, Chelsey A.

2008 Strontium and Geolocation, the Pathway to Identification for Deceased Undocumented Mexican BorderCrossers: A Preliminary Report. Journal of Forensic Science 53:46-49.

Katz, Solomon H., Mary L. Hediger, and Linda A. Valleroy 1974 Traditional Maize Processing Techniques in the New World. Science 184:765-773.

Levinson, A. A., Boaz Luz, and Yehoshua Kolodny 1987 Variations in Oxygen Isotopic Compositions of 
Human Teeth and Urinary Stones. Applied Geochemistry 2:367-371.

Manzanilla, Linda R.

1996 Corporate Groups and Domestic Activities at Teotihuacan. Latin American Antiquity 7:228-246.

2011 Sistemas de control de mano de obra y del intercambio de bienes suntuarios en el corredor Teotihuacano hacia la Costa del Golfo en el Clásico. Anales de Antropología 45:9-32.

Manzanilla, Linda R. (editor)

2017 Multiethnicity and Migration at Teopancazco: Investigations of a Teotihuacan Neighborhood. University Press of Florida, Gainesville.

Michelet, Dominique, and Grégory Pereira

2009 Teotihuacan y el occidente de México. In Teotihuacan: Ciudad de los Dioses, edited by Felipe R. Solís Olguín, Martierene Alcántara, and Gilda Castillo, pp. 79-84. Instituto Nacional de Antropología e Historia, Mexico City.

Millon, René

1973 The Teotihuacan Map. Part One: Text. University of Texas Press, Austin.

1981 Teotihuacan: City, State, and Civilization. In Supplement to the Handbook of Middle American Indians, Vol. 1: Archaeology, edited by Jeremy A. Sabloff, pp. 198-243. University of Texas Press, Austin.

Montgomery, Janet, Jane Evans, Simon Chenery, Vanessa Pashley, and Kristina Killgrove

2010 "Gleaming, White and Deadly": Using Lead to Track Human Exposure and Geographic Origins in the Roman Period in Britain. Journal of Roman Archaeology; Supplementary Series 78(September):199-226.

Murakami, Tatsuya, Gregory Hodgins, and Arleyn W. Simon 2013 Characterization of Lime Carbonates in Plasters from Teotihuacan, Mexico: Preliminary Results of Cathodoluminescence and Carbon Isotope Analysis. Journal of Archaeological Science 40:960-970.

Nado, Kristin L., Natalya Zolotova, and Kelly J. Knudson

2017 Paleodietary Analysis of the Sacrificial Victims from the Feathered Serpent Pyramid, Teotihuacan. Archaeological and Anthropological Sciences 9:117-132.

Nichols, Deborah L., Michael W. Spence, and Mark D. Borland

1991 Watering the Fields of Teotihuacan: Early Integration at the Ancient City. Ancient Mesoamerica 2:119-129.

Pacheco-Forés, Sofía, Gwyneth W. Gordon, and Kelly J. Knudson

2020 Expanding Radiogenic Strontium Isotope Baseline Data for Central Mexican Paleomobility Studies. PLoS ONE 15(2):e0229687.

Pederzani, Sarah, and Kate Britton

2019 Oxygen Isotopes in Bioarchaeology: Principles and Applications, Challenges and Opportunities. EarthScience Reviews 188:77-107.

Price, T. Douglas, Linda Manzanilla, and William D. Middleton

2000 Immigration and the Ancient City of Teotihuacan in Mexico: A Study Using Strontium Isotope Ratios in Human Bone and Teeth. Journal of Archaeological Science 27:903-913.

Price, T. Douglas, Michael W. Spence, and Fred J. Longstaffe

2020 The Temple of Quetzalcoatl, Teotihuacan: New Data on the Origins of the Sacrificial Victims. Ancient Mesoamerica, in press. DOI:10.1017/S095653611900035X.

Rattray, Evelyn

2004 Etnicidad en el Barrio de los Comerciantes,
Teotihuacan, y sus relaciones con Veracruz. In $L a$ costa del Golfo en tiempos teotihuacanos: Propuestas y perspectivas, edited by María Elena Ruiz and Arturo Pascual, pp. 493-513. Instituto Nacional de Antropología e Historia, Mexico City.

Renson, Virginie, Marx Navarro-Castillo, Andrea Cucina, Brendan J. Culleton, Douglas J. Kennett, and Hector Neff

2019 Origins and Diet of Inhabitants of the Pacific Coast of Southern Mexico during the Classic Period-Sr, C, and N Isotopes. Journal of Archaeological Science: Reports 27:101981.

Richter, Frank M., David B. Rowley, and Donald J. Paolo 1992 Sr Isotope Evolution of Seawater: The Role of Tectonics. Earth and Planetary Science Letters 109:11-23.

Schaaf, Peter, Gabriela Solís, Linda R. Manzanilla, Teodoro Hernández, Becket Lailson, and Peter Horn

2012 Isótopos de estroncio aplicados a estudios de migración humana en el centro de barrio de Teopancazco, Teotihuacan. In Estudios arqueométricos del centro de barrio de Teopancazco en Teotihuacan, México, edited by Linda R. Manzanilla, pp. 425-448. Universidad Nacional Autónoma de México, Mexico City.

Sheehy, James J.

1992 Ceramic Production in Ancient Teotihuacan, Mexico: A Case Study of Tlajinga 33. PhD dissertation, Department of Anthropology, Pennsylvania State University, University Park.

Smith, Michael E.

2020 Mesoamerica's First World City: Teotihuacan in Comparative Perspective. In Teotihuacan: The World Beyond the City, edited by David M. Carballo, Kenneth G. Hirth, and Barbara Arroyo, pp. 33-56. Dumbarton Oaks, Washington, DC.

Smith, Michael E., Abhishek Chatterjee, Angela C. Huster, and Sierra Stewart

2019 Apartment Compounds, Households, and Population in the Ancient City of Teotihuacan, Mexico. Ancient Mesoamerica 30:399-418.

Solís Pichardo, Gabriela, Peter Schaaf, Teodoro Hernández Treviño, Becket Lailson, Linda R. Manzanilla, and Peter Horn

2017 Migrants in Teopancazco: Evidence from Strontium Isotope Studies. In Multiethnicity and Migration at Teopancazco: Investigations of a Teotihuacan Neighborhood, edited by Linda R. Manzanilla, pp. 143-163. University Press of Florida, Gainesville.

Sommerville, Andrew D., Andrew W. Froehle, and Margaret J. Schoeninger

2018 Environmental Influences on Rabbit and Hare Bone Isotope Abundances: Implications for Paleoenvironmental Research. Palaeogeography, Palaeoclimatology, Palaeoecology 497:91-104.

Spence, Michael W., Christine D. White, Evelyn C. Rattray, and Fred J. Longstaffe

2005 Past Lives in Different Places: The Origins and Relationships of Teotihuacan's Foreign Residents. In Settlement, Subsistence, and Social Complexity: Essays Honoring the Legacy of Jeffrey R. Parsons, edited by Richard E. Blanton, pp. 155-197. Cotsen Institute of Archaeology, University of California, Los Angeles.

Storey, Rebecca

1992 Life and Death in the Ancient City of Teotihuacan: A Modern Paleodemographic Synthesis. University of Alabama Press, Tuscaloosa. 
Storey, Rebecca, Gina M. Buckley, and Douglas J. Kennett 2019 Residential Burial along the Southern Street of the Dead: Skeletons and Isotopes. Ancient Mesoamerica 30:147-161.

Taube, Karl A.

2003 Tetitla and the Maya Presence at Teotihuacan. In The Maya and Teotihuacan: Reinterpreting Early Classic Interaction, edited by Geoffrey E. Braswell, pp. 273314. University of Texas Press, Austin.

White, Christine D., T. Douglas Price, and Fred J. Longstaffe 2007 Residential Histories of the Human Sacrifices at the Moon Pyramid, Teotihuacan: Evidence from Oxygen and Strontium Isotopes. Ancient Mesoamerica 18:159-172.

White, Christine D., Michael W. Spence, Fred J. Longstaffe, and Kimberley R. Law

2000 Testing the Nature of Teotihuacán Imperialism at Kaminaljuyú Using Phosphate OxygenIsotope Ratios. Journal of Anthropological Research 56:535-558.

2004 Demography and Ethnic Continuity in the Tlailotlacan Enclave of Teotihuacan: The Evidence from Stable Oxygen Isotopes. Journal of Anthropological Archaeology 23:385-403.

White, Christine D., Michael W. Spence, Fred J. Longstaffe, Hilary Stuart-Williams, and Kimberley R. Law

2002 Geographic Identities of the Sacrificial Victims from the Feathered Serpent Pyramid, Teotihuacan: Implications for the Nature of State Power. Latin American Antiquity 13:217-236.

White, Christine D., Rebecca Storey, Fred J. Longstaffe, and Michael W. Spence

2004 Immigration, Assimilation, and Status in the Ancient City of Teotihuacan: Stable Isotopic Evidence from Tlajinga 33. Latin American Antiquity 15:176-198.
Widmer, Randolph J.

1987 The Evolution of Form and Function in a Teotihuacan Apartment Compound: The Case of Tlajinga 33. In Teotihuacan: Nuevos datos, nueva síntesis, nuevos problemas, edited by Emily McClung de Tapia and Evelyn C. Rattray, pp. 317-368. Universidad Nacional Autónoma de México, Mexico City.

2019 Lapidary Craft Production at 17:S3E1 and 18:S3E1, the Tlajinga District, Teotihuacan. Ancient Mesoamerica 30:181-197.

Widmer, Randolph J., and Rebecca Storey

2012 The "Tlajinga Barrio": A Distinctive Cluster of Neighborhoods in Teotihuacan. In The Neighborhood as a Social and Spatial Unit in Mesoamerican Cities, edited by M. Charlotte Arnauld, Linda R. Manzanilla, and Michael E. Smith, pp. 102-116. University of Arizona Press, Tucson.

Wright, Lori E.

2012 Immigration to Tikal, Guatemala: Evidence from Stable Strontium and Oxygen Isotopes. Journal of Anthropological Archaeology 31:334-352.

2013 Examining Childhood Diets at Kaminaljuyu, Guatemala, through Stable Isotopic Analysis of Sequential Enamel Microsamples. Archaeometry 55:113-133.

Wright, Lori E., and Henry P. Schwarcz

1999 Correspondence between Stable Carbon, Oxygen and Nitrogen Isotopes in Human Tooth Enamel and Dentine: Infant Diets at Kaminaljuyu. Journal of Archaeological Science 26:1159-1170.

Submitted June 12, 2020; Revised December 19, 2020; Accepted February 10, 2021 